\title{
Reelin Regulates Postnatal Neurogenesis and Enhances Spine Hypertrophy and Long-Term Potentiation
}

\author{
Lluís Pujadas, ${ }^{1,2,3}$ Agnès Gruart, ${ }^{4}$ Carles Bosch,,${ }^{1,2,3}$ Lídia Delgado, ${ }^{1,2,3}$ Cátia M. Teixeira, ${ }^{1,2,3}$ Daniela Rossi, ${ }^{1,2,3}$ \\ Luis de Lecea, ${ }^{5}$ Albert Martínez, ${ }^{1,2,3}$ José M. Delgado-García, ${ }^{4}$ and Eduardo Soriano ${ }^{1,2,3}$ \\ ${ }^{1}$ Developmental Neurobiology and Regeneration Laboratory, Institute for Research in Biomedicine, Barcelona, ${ }^{2}$ Department of Cell Biology, University of \\ Barcelona, and ${ }^{3}$ Centro de Investigación en Red sobre Enfermedades Neurodegenerativas (CIBERNED-ISCIII), 08028 Barcelona, Spain, ${ }^{4}$ Neurosciences \\ Division, Faculty of Experimental Sciences, University Pablo de Olavide, 41013 Sevilla, Spain, and ${ }^{5}$ Department of Molecular Biology, Department of \\ Psychiatry and Behavioral Sciences, Stanford University, Palo Alto, California 94304
}

Reelin, an extracellular protein essential for neural migration and lamination, is also expressed in the adult brain. To unravel the function of this protein in the adult forebrain, we generated transgenic mice that overexpress Reelin under the control of the CaMKII $\alpha$ promoter. Overexpression of Reelin increased adult neurogenesis and impaired the migration and positioning of adult-generated neurons. In the hippocampus, the overexpression of Reelin resulted in an increase in synaptic contacts and hypertrophy of dendritic spines. Induction of long-term potentiation (LTP) in alert-behaving mice showed that Reelin overexpression evokes a dramatic increase in LTP responses. Hippocampal field EPSP during a classical conditioning paradigm was also increased in these mice. Our results indicate that Reelin levels in the adult brain regulate neurogenesis and migration, as well as the structural and functional properties of synapses. These observations suggest that Reelin controls developmental processes that remain active in the adult brain.

\section{Introduction}

Reelin is an extracellular protein that is essential for neuronal migration and brain development (D'Arcangelo et al., 1995; Alcantara et al., 1998; Rice and Curran, 2001; Soriano and Del Rio, 2005; Cooper, 2008). Functions exerted by Reelin are mediated through the receptors apolipoprotein $\mathrm{E}$ receptor 2 (ApoER2) and very-low-density lipoprotein receptor (VLDLR), which trigger a complex signaling cascade involving members of the Src kinase family, the adaptor Dab1, the PI3K, Erk1/2 and GSK3 $\beta$ kinases, and CrkL, among others (Howell et al., 1997, 1999; Hiesberger et al., 1999; Beffert et al., 2002; Arnaud et al., 2003; Ballif et al., 2004; González-Billault et al., 2005; Simó et al., 2007).

In the adult brain, Reelin is expressed by subsets of neurons in the cerebral cortex, in particular by GABAergic interneurons (Alcantara et al., 1998). Although the role of Reelin in the adult brain is not well understood, it has been shown that this protein is expressed in synaptic contacts, and that neurons deficient in

\footnotetext{
Received 0ct. 23, 2009; revised Jan. 19, 2010; accepted Feb. 18, 2010.

This project was supported by Grant BFU2008-3980 [Ministerio de Ciencia e Innovacion (MICINN), Spain] and grants from The "Marató de TV3" and "Caixa Catalunya-Obra Social" Foundations to E.S. and by Grants P107/0715 (Fondo de Investigación Sanitaria) to A.M., BFU2008-03390/BMC (MICINN) to A.G., and BFU2008-00899 (MICINN) to J.M.D.-G. We thank Drs. M. Mayford (Scripps Research Institute, La Jolla, CA), J. A. Cooper (Fred Hutchinson Cancer Research Center, Seattle, WA), T. Curran (Joseph Stokes Jr. Research Institute, Philadelphia, PA), and A. M. Goffinet (Université Catholique de Louvain, Brussels, Belgium) for generously providing materials used in this study; $\mathrm{M}$. Esteban for contributing to physiology experiments and providing technical assistance; C. Díaz-Ruiz, J. M. Ureña, and A. La Torre for scientific comments; B. Pintado, E. M. Pastor, and L. Brunso for technical assistance; and Tanya Yates for editorial help.

Correspondence should be addressed to either Lluís Pujadas or Eduardo Soriano, Developmental Neurobiology and Regeneration Laboratory (PS1-A1), Institute for Research in Biomedicine, Barcelona, Barcelona Science Park Baldiri Reixac, 10, 08028 Barcelona, Spain, E-mail: Iluis.pujadas@irbbarcelona.org or eduardo.soriano@ irbbarcelona.org.

DOI:10.1523/JNEUROSCI.5284-09.2010

Copyright $\odot 2010$ the authors $\quad 0270-6474 / 10 / 304636-14 \$ 15.00 / 0$
}

ApoER2 and VLDLR receptors have impaired long-term potentiation (LTP) (Pesold et al., 1998; Beffert et al., 2005). Recently, it has been demonstrated that Reelin participates in the composition, recruitment and traffic of NMDA receptor subunits (Chen et al., 2005; Qiu et al., 2006; Groc et al., 2007), in the generation of dendrites, and in the formation of dendritic spines (Matsuki et al., 2008; Niu et al., 2008). Furthermore, the lack of spines in cultured reeler neurons is recovered by incubation with Reelin (Matsuki et al., 2008; Niu et al., 2008). Altogether, these studies suggest that Reelin is involved in the correct formation and maintenance of synapses. This protein also acts as a detachment factor in the migration of subventricular zone (SVZ)-derived neurons in the rostral migratory stream (RMS) to the olfactory bulb (OB) (Hack et al., 2002). Moreover, deficits in Reelin levels and genetic variants have been associated with several psychiatric disorders (Impagnatiello et al., 1998; Persico et al., 2001), which, together with studies demonstrating altered Reelin levels in Alzheimer's disease, the localization of Reelin with $\beta$-amyloid deposits, and the importance of Reelin in neurodegeneration and $\beta$-amyloidinduced synaptic depression (Beffert et al., 2006; Botella-López et al., 2006; Durakoglugil et al., 2009; Knuesel et al., 2009), supports the notion that this protein participates in the pathogenesis of neurological diseases.

Most studies on Reelin functions in the adult brain have been based on analyses of the Reelin-deficient reeler mice and heterozygous reeler mice, as a model of Reelin haploinsufficiency. Studies in reeler mice are hampered by the dramatic defects in brain lamination and organization, which raises the question as to whether defects in reeler mouse function are secondary to the mispositioning of neurons. Moreover, transgenic mice expressing Reelin under the control of the Nestin promoter rescue the 
reeler phenotype in the cerebellum but not in the cerebral cortex (Magdaleno et al., 2002). To unravel the function of Reelin in the adult brain, we generated a gain-of-function transgenic mouse model that overexpresses Reelin specifically in the postnatal and adult forebrain, under the control of the calcium-calmodulindependent kinase II $\alpha$ promoter ( $\mathrm{pCaMKII} \alpha)$. Our data provide evidence that Reelin regulates adult hippocampal neurogenesis, the positioning of adult-generated neurons, and the structural, functional, and plastic properties of hippocampal synapses. These results indicate that, in the adult brain, Reelin participates in the control of processes that are reminiscent of developmental processes.

\section{Materials and Methods}

Generation of $\operatorname{Tg} 1 / \operatorname{Tg} 2$ mice. Total digestion of pCrlM (D'Arcangelo et al., 1997) was performed with NotI to linearize the $16 \mathrm{~kb}$ vector. Then, partial digestion with EcoRI for $10 \mathrm{~min}$ at $37^{\circ} \mathrm{C}$ was performed to obtain a mixture of partially digested species. The $10.6 \mathrm{~kb}$ fragment, containing the Myc-tagged cDNA of Reelin (rlM), was purified and subcloned into the EcoRI-NotI sites of the pCRII-TOPO cloning vector (Invitrogen). A $10.6 \mathrm{~kb}$ fragment was then excised by SpeI total digestion, overhanging ends were refilled using Cloned Pfu DNA polymerase (Stratagene), and the fragment was subcloned into the EcoRV site of the PMM400 vector (provided by Dr. M. Mayford, Scripps Research Institute, La Jolla, CA). The newly generated PMM-rlM vector was digested with NotI to obtain an injection fragment of $12.6 \mathrm{~kb}$, which contained the tetracycline operator (tetO), the Myc-tagged Reelin cDNA flanked by 2 intronic sequences, and the SV40 poly-A site.

Microinjections of single-cell CBAxC57BL/6J mice embryos with PMM-rlM construction were performed in the Department of Animal Reproduction (Instituto Nacional de Investigación y Tecnología Agraria y Alimentaria, Madrid, Spain), and the embryos were implanted in pregnant females to obtain founding animals. Mice were bred in the animal research facility at the Barcelona Science Park (SEA-PCB). They were provided with food and water ad libitum and maintained in a temperature-controlled environment in a $12 / 12 \mathrm{~h}$ light-dark cycle. Reelin-transgenic mice founders (Tg2) were identified by PCR. Genomic DNA was purified using Invisorb spin tissue mini kit (Invitek), and PCR amplifications on exon 26 and exon 27 were performed using the following primers (Invitrogen): RLgen-F: 5' -TTGTACCAGGTTCCGCTGGT3', RLgen-R: 5'-GCACATATCCAGGTTTCAGG-3' . A 320 bp fragment was amplified in $\mathrm{Tg} 2$ mice, while the same pair of primers also amplifies the endogenous reelin gene fragment of $720 \mathrm{bp}$, containing the $400 \mathrm{bp}$ intron 26. Confirmed founder mice $(\mathrm{Tg} 2)$ were then crossed with wildtype C57BL/6J mice to obtain progeny. Following generations of $\mathrm{Tg} 2$ mice were crossed with pCaMKII $\alpha$-tTA (Tg1) animals to obtain double transgenic mice overexpressing Reelin $(\operatorname{Tg} 1 / \operatorname{Tg} 2)$. The $T g 1$ strain was provided by M. Mayford and genotyped as described previously (Mayford et al., 1996). For doxycycline treatment, adult mice were fed with doxycycline (Bio-Serv, $200 \mathrm{mg} / \mathrm{kg}$ ) for $1-4$ weeks before they were killed.

All the experiments using animals were performed in accordance with the European Community Council directive and the National Institute of Health guidelines for the care and use of laboratory animals. Experiments were also approved by the local ethical committees.

Antibodies and reagents. Mouse monoclonal anti-Reelin antibody (clone G10) was provided by Dr. A. M. Goffinet (Université Catholique de Louvain, Brussels, Belgium) and affinity-purified antibody anti-Dab1 (B3) by Dr. J. A. Cooper (Fred Hutchinson Cancer Research Center, Seattle, WA). The commercial primary antibodies used were as follows: anti-Reelin (clone G10) (Millipore Bioscience Research Reagents), antiDCX (Millipore Bioscience Research Reagents), anti-PSA-NCAM (ABCYS), anti-5-bromo-2'-deoxyuridine (BrdU) (Acrys), anti-NeuN (Millipore Bioscience Research Reagents), anti-GFAP (DAKO), antiactin (Millipore Bioscience Research Reagents), anti-parvalbumin (Swant), anti-calbindin (Swant), anti-calretinin (Swant), anti-tyrosine hydroxylase (TH) (Millipore Bioscience Research Reagents), and anti-Tbr-1 (Millipore Bioscience Research Reagents). The HRP-labeled secondary antibodies used for Western blot were from DAKO. Fluorescent secondary antibodies were from Invitrogen. Biotinylated-secondary antibodies and streptavidin-biotinylated/HRP complex were from GE Healthcare. $\mathrm{F}\left(\mathrm{ab}^{\prime}\right)_{2}$ fragment antimouse IgG was from Jackson ImmunoResearch.

BrdU, bisbenzimide (Hoechst 33342), diaminobenzidine reagent (DAB), nickel ammonium sulfate, and hydrogen peroxide $\left(\mathrm{H}_{2} \mathrm{O}_{2}\right)$ were from Sigma.

$R N A$ purification and $q R T-P C R$ analysis. For RNA purification from brain tissues, animals were killed by dislocation, and brains were immediately removed. Specific brain regions were rapidly dissected, frozen in liquid nitrogen, and stored at $-80^{\circ} \mathrm{C}$ before processing. Total RNA was extracted using Trizol (Invitrogen) reagent following the instruction manual. In brief, tissue homogenization was performed in $1 \mathrm{ml}$ of Trizol reagent per 50-100 mg of tissue using power homogenizer (Polytron). Phase separation was provoked by addition of chloroform. RNA from the aqueous phase was precipitated by adding isopropyl alcohol, and after washing RNA with 75\% ethanol and air-drying, RNA was redissolved in RNase-free water (Ambion). RNA quality and concentration was determined by absorbance at 260 and $280 \mathrm{~nm}$ in a nanodrop (Agilent) and by analysis using a bioanalyzer (Agilent).

Five nanograms of RNA per sample were reverse transcribed using Superscript (Invitrogen) and amplified with Ovation System (NuGEN). For gene expression assays, we used FAM dye-labeled Taqman MGB probes specific for the target gene Reelin (Mm00465200_m1) and for the reference gene Actb (Mm00607939_s1). Reactions were developed in ABI PRISM 7700 Sequence Detection System (Applied Biosystems) in a 96-well plate using the following conditions: $95^{\circ} \mathrm{C}$ for $10 \mathrm{~min}$ followed by 40 cycles of $95^{\circ} \mathrm{C}$ for $15 \mathrm{~s}$ and $60^{\circ} \mathrm{C}$ for $1 \mathrm{~min}$ (volume of reaction was 12 $\mu l)$. To ensure equal efficiencies for the target and reference amplifications, we amplified dilutions from the template (from 0.1 to $100 \mathrm{ng}$ of ssDNA) and calculated the absolute value of the slope of log input amount versus $\Delta \mathrm{C}_{\mathrm{T}}$ (slope $0.0592<0.1$ ). For quantification, we used three replicates per sample from five mice per group ( 5 months old). Relative quantification was determined using the comparative $C_{T}$ method as described in the ABI PRISM users manual.

Western blots. Brain dissection for Western blot analysis was performed as for RNA. Pieces of tissues were also lysed using power homogenizer (Polytron) in lysis buffer (50 mM HEPES, pH 7.5, 150 mm sodium chloride, $1.5 \mathrm{~mm}$ magnesium chloride, $1 \mathrm{~mm}$ EGTA, 10\% glycerol, and $1 \%$ Triton X-100) containing Complete Mini protease inhibitor cocktail (Roche) and phosphatase inhibitors (10 mm tetra-sodium pyrophosphate, $200 \mu \mathrm{m}$ sodium orthovanadate, and $10 \mathrm{~mm}$ sodium fluoride). Samples were sonicated, insoluble debris was removed by centrifugation ( $15 \mathrm{~min}, 16,000 \times \mathrm{g}$ ), and supernatants were stored at $-80^{\circ} \mathrm{C}$.

Samples were diluted 1:6 with $6 \times$ loading buffer $(0.5 \mathrm{~m}$ Tris- $\mathrm{HCl}, \mathrm{pH}$ 6.8, $2.15 \mathrm{~m} \beta$-mercaptoethanol, $10 \%$ SDS, 30\% glycerol, and $0.012 \%$ bromophenol blue), boiled for $3 \mathrm{~min}$ at $95^{\circ} \mathrm{C}$, resolved by SDSpolyacrylamide gels, and transferred onto nitrocellulose membranes. Membranes were blocked for $1 \mathrm{~h}$ at room temperature (RT) in TBST $[10 \mathrm{~mm}$ Tris, pH 7.4, 140 mm sodium chloride (TBS) with $0.1 \%$ Tween 20] containing $5 \%$ nonfat milk. Primary antibodies were incubated for $90 \mathrm{~min}$ in TBST$0.02 \%$ azide [anti-Reelin (clone G10) 1:1000, anti-mDab1 (B3) 1:2000, and anti-actin 1:100,000]. After incubation with secondary HRP-labeled antibodies for $1 \mathrm{~h}$ at RT (diluted 1:2000 in TBST-5\% nonfat milk), membranes were developed with the ECL+ system (GE Healthcare).

BrdU administration. Intraperitoneal injections of BrdU were administered at a dose of $50 \mathrm{mg} / \mathrm{kg}$. P15 and 2-month-old mice received two injections and 5-month-old mice received five injections ( $2 \mathrm{~h}$ interval). Animals were scarified 1,10 , or $20 \mathrm{~d}$ after the last injection and then processed for histology.

Histology. Animals were anesthetized and perfused for $20 \mathrm{~min}$ with 0.1 M phosphate buffer (PB) containing 4\% of paraformaldehyde (PF). Brains were removed, postfixed overnight with $\mathrm{PB}-4 \% \mathrm{PF}$, cryoprotected with $\mathrm{PB}-30 \%$ sucrose, and frozen. To obtain tissue sections, brains were sectioned coronally at $30 \mu \mathrm{m}$, distributed in 10 series, and maintained at $-20^{\circ} \mathrm{C}$ in PB-30\% glycerol-30\% ethylene glycol. Nuclei were detected using Nissl staining.

For immunodetection of antigens, sections were blocked for $2 \mathrm{~h}$ at RT with PBS containing $10 \%$ of normal goat serum (NGS), $0.2 \%$ of gelatin, and $\mathrm{F}\left(\mathrm{ab}^{\prime}\right)_{2}$ fragment anti-mouse IgG (1:300) when needed. For BrdU 
detection, nuclear permeabilization was performed before blocking. Primary antibodies were incubated overnight at $4{ }^{\circ} \mathrm{C}$ with PBS-5\% NGS. For immunohistofluorescence, dyelabeled secondary antibodies (1:500) were incubated for $2 \mathrm{~h}$ at RT in PBS-5\% NGS, then sections were counterstained with bisbenzimide $(5 \mu \mathrm{M})$, mounted in Mowiol, and stored at $-20^{\circ} \mathrm{C}$. For immunohistochemistry, sequential incubation with biotinylated secondary antibodies (1:200; $2 \mathrm{~h}$ at RT) and streptavidin-HRP (1: 400; $2 \mathrm{~h}$ at RT) was performed in PBS-5\% NGS. Bound antibodies were visualized by reaction using $\mathrm{DAB}$ and $\mathrm{H}_{2} \mathrm{O}_{2}$ as peroxidase substrates, adding nickel ammonium sulfate in the solution in some cases. Finally, sections were dehydrated and mounted (Eukitt). BrdU-immunostained sections were also immunolabeled with anti-NeuN antibodies.

Electron microscopy. Adult Reelin transgenic mice $(n=3)$ and control littermates $(n=3)$ were perfused with $2 \%$ glutaraldehyde- $2 \%$ paraformaldehyde in $0.12 \mathrm{~m}$ phosphate buffer. After postfixation in the same solution overnight, tissue slices were transferred to $2 \%$ osmium tetroxide, stained with $2 \%$ uranyl acetate, dehydrated, and finally embedded in Araldite. Ultrathin sections were collected on formvar-coated slot grids and stained with lead citrate. Electron micrographs covering $67 \mu \mathrm{m}^{2}$ (final magnification 20,000 $\times$ ) were randomly taken from each hippocampal layer, and the density of synaptic terminals and dendritic spines, establishing and receiving at least a synaptic contact, respectively, were calculated ( $n=46-69$ micrographs for each layer and group). In addition, boutons establishing at least two contacts were also counted. Statistical analysis was performed using the Student's $t$ test. An additional set of adult mice [wild type $(w t)$, $n=2 ; \operatorname{Tg} 1 / \operatorname{Tg} 2, n=2$; and $\operatorname{Tg} 1 / \operatorname{Tg} 2$ mice treated with doxycycline for $7 \mathrm{~d}, n=3$ ] were processed for electron microscopy and analyzed as above.

Digital pictures of selected dendritic segments from pyramidal cells, located at the same level in the stratum radiatum of the CA1 region, were captured at a magnification of $26,500 \times$. Three series per group were analyzed, ranging from 15 to 20 sections. Dendritic segments were three-dimensionally reconstructed with the aid of Reconstruct software (Reconstruct 1.0.5.7), and the number of dendritic spines reaching $0.4 \mu \mathrm{m}$ in diameter was counted $(n=3$ reconstructed dendritic segments per animal group, with a total of $32-43$ spines per group).

Surgery. Animals were anesthetized with 1-3\% halothane (AstraZeneca) delivered from a calibrated Fluotec 5 (Fluotec-Ohmeda) vaporizer at a flow rate of $1-4 \mathrm{~L} / \mathrm{min}$ oxygen. Animals were implanted with bipolar stimulating electrodes in the right (contralateral) Schaffer collateralcommissural pathway of the dorsal hippocampus ( $2 \mathrm{~mm}$ lateral and 1.5 $\mathrm{mm}$ posterior to bregma; depth from the brain surface, $1.0-1.5 \mathrm{~mm}$ ) (Paxinos and Franklin, 2001) and with a recording electrode in the ipsilateral stratum radiatum underneath the CA1 area $(1.2 \mathrm{~mm}$ lateral and $2.2 \mathrm{~mm}$ posterior to bregma; depth from the brain surface, $1.0-1.5 \mathrm{~mm}$ ). These electrodes were made of $50 \mu \mathrm{m}$, Teflon-coated tungsten wire (Advent Research Materials). The final position of hippocampal electrodes was determined under recording procedures. A $0.1 \mathrm{~mm}$ bare silver wire was affixed to the skull as a ground. The eight wires were connected to two 4-pin sockets (RS-Amidata). The sockets were fixed to the skull with the help of two small screws and dental cement. Further details of im- b

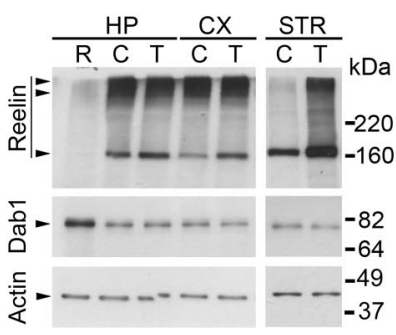

cx

STR

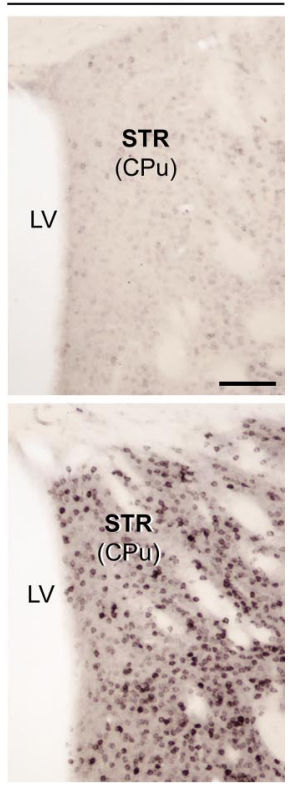
pComKla (in ic (al): Reelin is also expressed in neocortical pyramidal cells (bottom middle) and in striatal neurons (bottom right). I-VI, Cortica layers; $\mathrm{CA1}$-CA3, hippocampal regions; $\mathrm{CPu}$, caudate-putamen nucleus; DOX, doxycycline; $\mathrm{H}$, hilus; LV, lateral ventricle; ML, molecular layer; SP, stratum pyramidale; WM, white matter. Scale bars: c (left): $200 \mu \mathrm{m} ; \mathrm{c}$ (middle and right): $100 \mu \mathrm{m}$.

plantation procedures have been explained previously (Gruart et al., 2006). Animals used in conditioning were also implanted with bipolar recording electrodes in the left orbicularis oculi muscle and with bipolar stimulating electrodes on the ipsilateral supraorbital nerve. Electrodes were made of $50 \mu \mathrm{m}$, Teflon-coated, annealed stainless steel wire (A-M Systems). Electrode tips were bare of the isolating cover for $0.5 \mathrm{~mm}$ and bent into a hook to facilitate a stable insertion in the upper eyelid.

Classical conditioning procedures. For classical conditioning, data were recorded from 15 animals per group. Three animals at a time were placed in separate small $(5 \times 5 \times 10 \mathrm{~cm})$ plastic chambers located inside a larger Faraday box $(30 \times 30 \times 20 \mathrm{~cm})$. Classical conditioning was achieved using a trace paradigm (see Fig. 10a) consisting of a tone $(20 \mathrm{~ms}, 2.4 \mathrm{kHz}$, $85 \mathrm{~dB}$ ) presented as a conditioned stimulus (CS). The unconditioned stimulus (US) consisted of a cathodal square pulse applied to the supraorbital nerve $(500 \mu \mathrm{s}, 3 \times$ threshold) $500 \mathrm{~ms}$ after the end of the CS. A total of 2 habituation, 10 conditioning, and 5 extinction sessions were performed for each animal. A conditioning session consisted of 60 CS-US presentations and lasted $30 \mathrm{~min}$. For a proper analysis of the CR, the CS was presented alone in $10 \%$ of the cases. CS-US presentations were separated at random by $30 \pm 5$ s. For habituation and extinction 

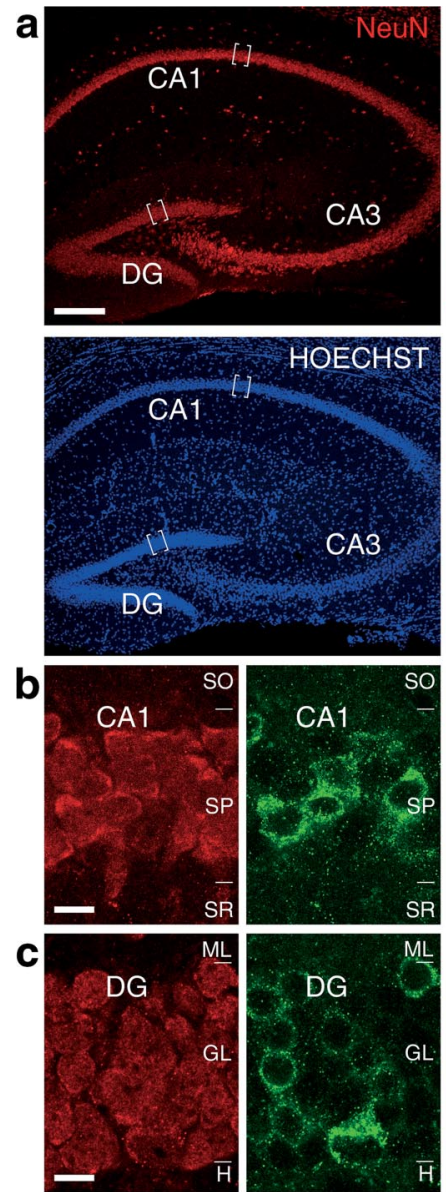
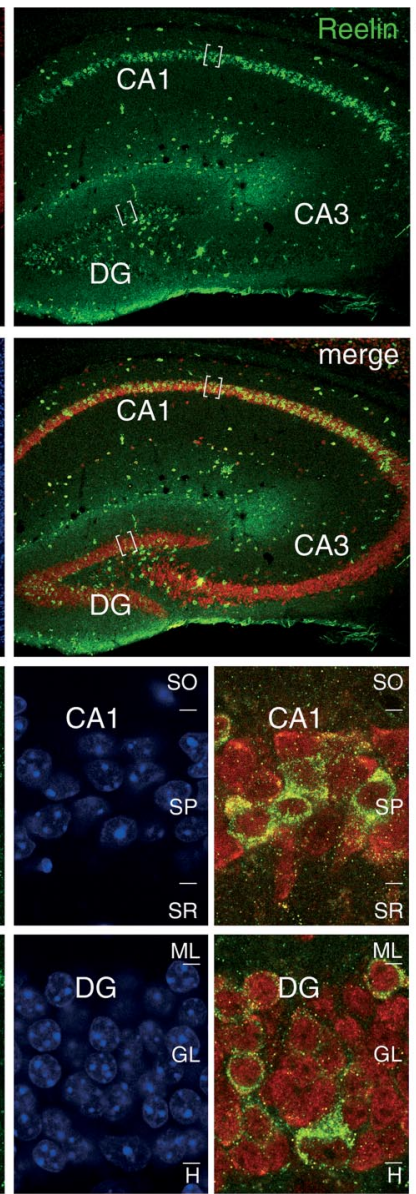
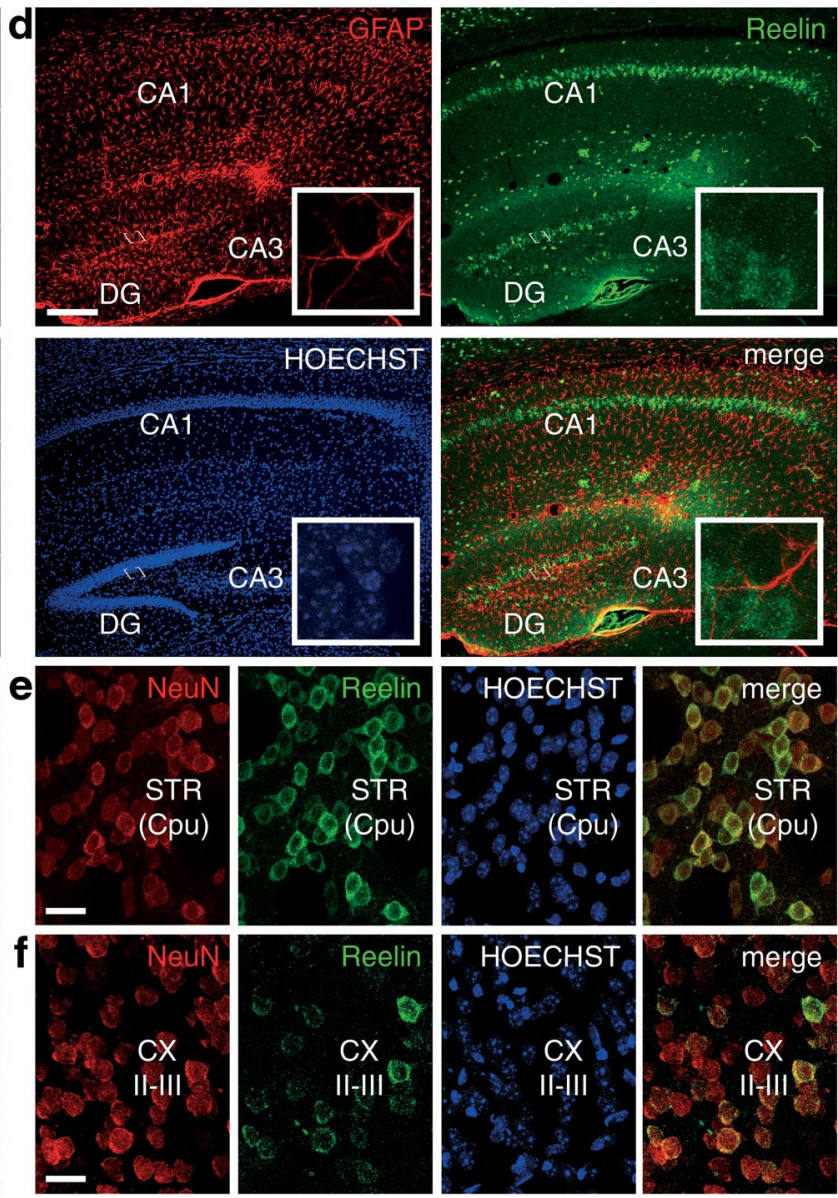

Figure 2. Double-immunohistofluorescence staining in tissue sections from adult $T g 1 / T g 2$ mice. $\boldsymbol{a}-\boldsymbol{c}$, Double immunodetection of Reelin (green) and the neuronal marker NeuN (red) in hippocampal tissue sections from $\mathrm{Tg} 1 / \mathrm{Tg} 2$ mice counterstained with DAPI (blue). $\boldsymbol{a}$, Low-power micrographs showing Reelin-expressing cells distributed throughout the hippocampal layers, including the CA1 pyramidal neurons and the granule cells. High-power micrographs from CA1 (b) and DG (c) regions, demonstrating that cells expressing Reelin are also positive for NeuN. $\boldsymbol{d}$, Double immunodetection of Reelin (green) and the glial marker GFAP (red) in hippocampal tissue sections from $\mathrm{Tg} 1 / \mathrm{Tg} 2$ mice counterstained with DAPI. The staining patterns for Reelin are not coincident with those for GFAP. Insets, High-power micrographs demonstrating that GFAP and Reelin immunoreactivities do not overlap. $\boldsymbol{e}, \boldsymbol{f}$, Double immunodetection of Reelin (green) and neuronal marker NeuN (red) in tissue sections from the striatum (STR) (e) and neocortex (CX) (f) of $\operatorname{Tg} 1 / \mathrm{Tg} 2$ mice counterstained with DAPI (blue). In both regions, Reelin-expressing cells are also NeuN positive. II-III, Cortical layers; CA1-CA3, hippocampal regions; CPu, caudate-putamen nucleus; H, hilus; ML, molecular layer; SP, stratum pyramidale. Scale bars: $\boldsymbol{a}, \boldsymbol{d}, 200 \mu \mathrm{m} ; \boldsymbol{b}, \boldsymbol{c}, \boldsymbol{e}, \boldsymbol{f}, 10 \mu \mathrm{m}$.

sessions, only the CS was presented, also for 60 times per session, at intervals of $30 \pm 5 \mathrm{~s}$ (Gruart et al., 2006).

Electrophysiological recordings and stimulation procedures. Recordings were made using six differential amplifiers with a bandwidth of $0.1-10$ $\mathrm{kHz}$ (P511, Grass-Telefactor). Hippocampal recordings were made with a high-impedance probe $\left(2 \times 10^{12} \Omega, 10 \mathrm{pF}\right)$. As criteria, during the CS-US interval, we considered a "CR" as the presence of EMG activity lasting $>10 \mathrm{~ms}$ and initiated $>50 \mathrm{~ms}$ after CS onset. In addition, the integrated EMG activity recorded during the CS-US interval had to be at least $2.5 \times$ greater than the averaged activity recorded immediately before CS presentation (Porras-García et al., 2005).

Electrodes were implanted in the CA1 area, using as a guide the field potential depth profile evoked by paired ( $40 \mathrm{~ms}$ of interval) pulses presented to the ipsilateral Schaffer collateral pathway. The recording electrode was fixed at the site where a reliable monosynaptic $(5 \mathrm{~ms})$ fEPSP was recorded. Synaptic field potentials in the CA1 area were evoked during habituation, conditioning, and extinction sessions by a single 100 $\mu$ s square, biphasic (negative-positive) pulse applied to Schaffer collaterals $300 \mathrm{~ms}$ after CS presentation. Stimulus intensities ranged from 50 to $400 \mu \mathrm{A}$. For each animal, the stimulus intensity was set well below the threshold for evoking a population spike, usually $30-40 \%$ of the intensity required for evoking a maximum fEPSP response (Gureviciene et al., 2004). An additional criterion for selecting stimulus intensity was that a second stimulus, presented $40 \mathrm{~ms}$ after a conditioning pulse, evoked a larger $(>20 \%)$ synaptic field potential (Bliss and Gardner-Medwin, 1973).
For evoking LTP (15 animals per group), we used a high-frequency stimulation (HFS) train consisting of five $200 \mathrm{~Hz}, 100 \mathrm{~ms}$ trains of pulses at a rate of $1 / \mathrm{s}$. This protocol was presented six times, at intervals of $1 \mathrm{~min}$. As indicated above for functional synaptic plasticity, pulse intensity (50$400 \mu \mathrm{A}$ ) was set at $30-40 \%$ of the amount required to evoke a maximum fEPSP response for baseline recordings and after the HFS train. To avoid evoking a population spike and/or unwanted electroencephalographic (EEG) seizures, the stimulus intensity during the HFS train was set at the same amount as that used for generating the baseline recording.

Statistical analysis. For quantifications in the $\mathrm{OB}$ (slices from $3.00 \mathrm{~mm}$ anterior to bregma), the number of $\mathrm{TH}-$, parvalbumin-, calretinin-, and calbindin-positive cells or BrdU-positive cells (20 d after BrdU injections) was counted every 10 th section for each animal; data were normalized to the area counted in 30- $\mu$ m-thick sections ( $n=8-10$ sections per animal, 3 animals per group). To quantify neurogenesis in the SVZ (from $0.09 \mathrm{~mm}$ to $0.00 \mathrm{~mm}$ anterior to bregma), we counted BrdU-positive cells ( $1 \mathrm{~d}$ after BrdU injections) from the lateral wall of the lateral ventricle every 10th section; data were represented as number of BrdU-positive cells per section containing 1 hemisphere ( $n=6$ sections per animal, 3 animals per group). To quantify proliferation in the RMS (from $2.65 \mathrm{~mm}$ to $2.00 \mathrm{~mm}$ anterior to bregma), we counted BrdU-positive cells (1 d after BrdU injections) every 10th section; data were normalized to the area containing BrdU-positive cells in 30 - $\mu \mathrm{m}$-thick sections containing 1 hemisphere ( $n=4-6$ sections per animal, $2-3$ animals per group). To quantify neurogenesis in the hippocampal dentate gyrus (from $1.35 \mathrm{~mm}$ to $2.30 \mathrm{~mm}$ posterior to bregma), we counted PSA-NCAM-, DCX-, and 
BrdU-positive cells $(1,10$, and $20 \mathrm{~d}$ after BrdU injections) in the subgranular zone (SGZ)/ granular layer (GL) layers; data were normalized to the longitude of the SGZ/GL layer counted in 30- $\mu \mathrm{m}$-thick sections containing one hemisphere ( $n=6$ sections per animal, 3-5 animals per group). Longitudes and areas measured for quantification were determined using ANALYSIS software. Significance was analyzed using the unpaired two-tailed Student's $t$ test. Data are represented as mean \pm SEM.

EMG and extracellular hippocampal activity, and $1 \mathrm{~V}$ rectangular pulses corresponding to CS and US presentations, were stored digitally on a computer through an analog/digital converter (CED 1401 Plus), at a sampling frequency of $11-22 \mathrm{kHz}$ and with an amplitude resolution of 12 bits. Data were analyzed offline for quantification of conditioned responses and fEPSP slopes with the help of commercial (Spike 2 and SIGAVG from CED and STATGRAPHICS PLUS 5.1) and homemade (Porras-García et al., 2005; Gruart et al., 2006) representation programs. The slope of evoked fEPSPs was computed as the first derivative (in volts per seconds) of fEPSP recordings (in volts). Five successive fEPSPs were averaged, and the mean value of the slope during the rise time period (i.e., the period of the slope between the initial $10 \%$ and the final $10 \%$ of the fEPSP) was determined. Computed results were processed for statistical analysis using the SigmaStat for Windows package. Linear regression analyses were used to determine the evolution of fEPSP across training. Unless otherwise indicated, data are represented as the mean \pm SEM. Acquired data were analyzed using a two-way ANOVA, with days as repeated measure. Contrast analysis was added for a further study of significant differences.

\section{Results}

\section{Conditional transgenic mice} overexpress Reelin in the adult forebrain

To study the role of Reelin in the postnatal and adult forebrain, we generated transgenic mouse lines that overexpress Reelin under the control of $p C a M K I I \alpha$. We first generated tetO-rlM transgenic mice ( $\mathrm{Tg} 2)$ by cloning a myc-tagged Reelin cDNA construct ( $r l M$ ) (D'Arcangelo et al., 1997) into a tetracycline-regulated system of gene expression (tetO) (Fig. 1a). To drive transgene expression specifically in the postnatal and adult forebrain, $\mathrm{Tg} 2$ mice were crossed with transgenic mice expressing a tetracycline-controlled transactivator $(t T A)$ under the control of the CaMKII $\alpha$ promoter (Mayford et al., 1996). In $p C a M K I I \alpha-t T A$ transgenic mice (Tg1), tTA expression is restricted to most forebrain neurons throughout the neocortex, hippocampus, amygdala, and striatum, thereby mimicking endogenous CaMKII $\alpha$ expression ( $\mathrm{Tg} 1 / \mathrm{Tg} 2)$ (Mayford et al., 1996). In double transgenic animals carrying both the tetO-rlM and $p C a M K I I \alpha-t T A$ transgenes $(T g 1 / T g 2)$, Reelin expression is directed by the CaMKII $\alpha$ promoter, in a regulated system that can be repressed by doxycycline administration (Fig. 1a).

To analyze the spatiotemporal patterns of Reelin expression, brain sections were processed for immunohistochemistry using the monoclonal G10 Reelin antibody. In wt young adult mice and b

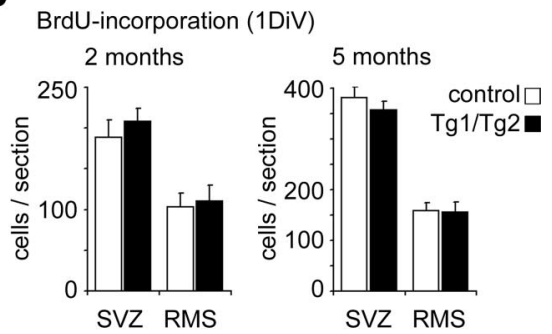

d

BrdU incorporation (5 months + 20DiV)

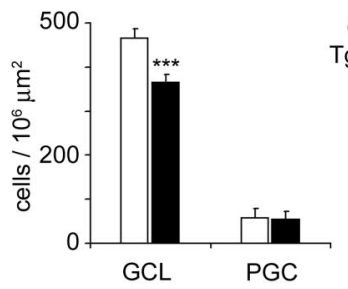

f

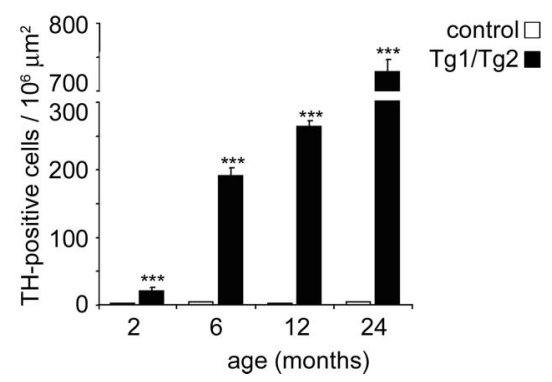

control $\square$ $\operatorname{Tg} 1 / \operatorname{Tg} 2$

Figure 3. Impairment of neural migration, but not neurogenesis, in the SVZ and RMS. $\boldsymbol{a}$, Representative images from the adult SVZ immunostained against BrdU after BrdU pulses $1 \mathrm{~d}$ earlier. Control and Tg1/Tg2 sections were counterstained with Nissl dye. (he in 列 ( PGC, periglomerular cell layer; LV, lateral ventricle; EPL, external plexiform layer; MCL, mitral cell layer; STR, striatum. Data are presented as mean \pm SEM; ${ }^{* * *} p<0.001$; Student's $t$ test. Scale bars: $\boldsymbol{a}, \boldsymbol{c}, \boldsymbol{e}, 100 \mu \mathrm{m}$.

in $\mathrm{Tg} 1 / w t$ and $w t / \mathrm{Tg} 2$ littermates, the pattern of Reelin expression was as described previously (Alcantara et al., 1998); thus, in the neocortex and hippocampus, numerous interneurons and a few surviving Cajal-Retzius cells were Reelin positive; in the OB, Reelin was expressed in mitral and periglomerular neurons, while a few neurons were faintly labeled in other regions, including the striatum (Fig. 1c, top; supplemental Fig. 1, available at www. jneurosci.org as supplemental material). In addition to the above pattern of expression, $\mathrm{Tg} 1 / \mathrm{Tg} 2$ mice exhibited a marked increase in Reelin immunostaining. Thus, in the cerebral cortex, numerous pyramidal cells in the neocortex, hippocampus (most remarkably in CA1 region), and entorhinal cortex were immunoreactive. The granule cells in the dentate gyrus (DG) were also Reelin positive. In the striatum (caudate and globus pallidus), a marked increase in expression was detected with a large percentage of striatal neurons being Reelin positive [Figs. $1 c$ (bottom), 2]. In the OB, there was an increase in Reelin immunostaining in mitral cells and in the plexiform layers (supplemental Fig. 1, available at www. jneurosci.org as supplemental material). Western blot analyses of 
a
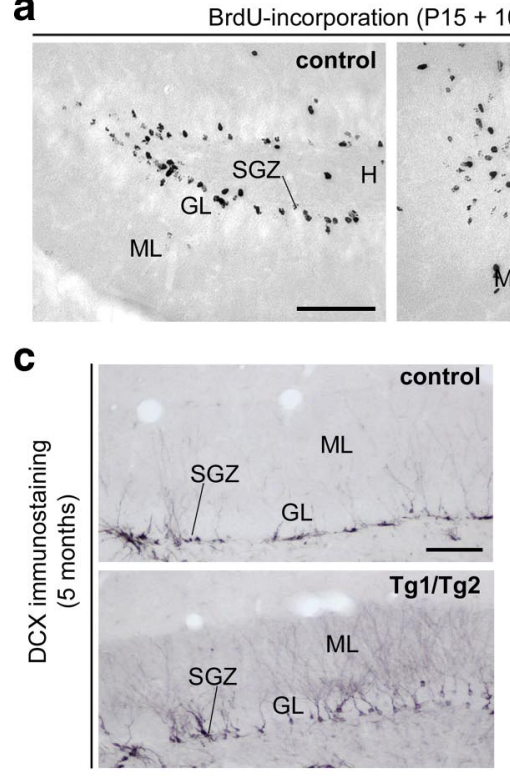

e
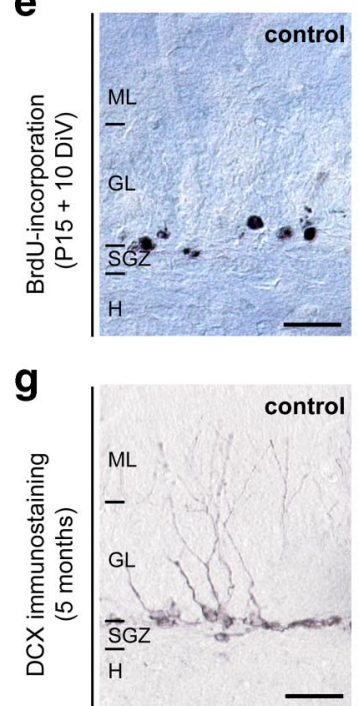

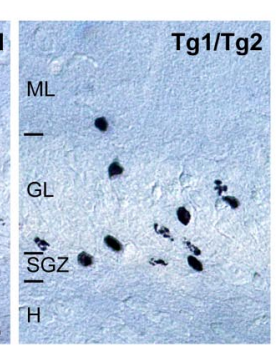

d 5 months

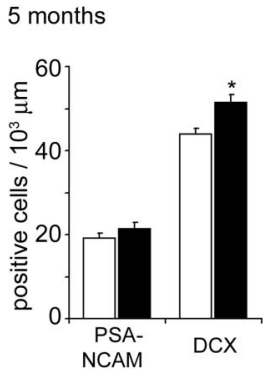

b

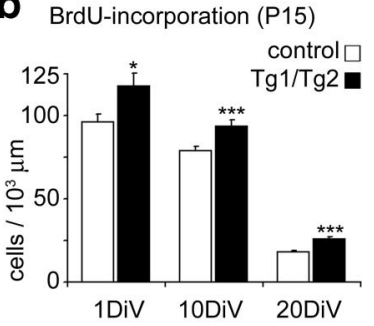

alterations, compared with control mice. Thus, cortical lamination in the cerebral cortex and $\mathrm{OB}$ and the numbers and densities of identified neural subpopulations were similar among the distinct genotypes (supplemental Fig. 3, available at www. jneurosci.org as supplemental material). Immunostaining against the glial and neuronal markers GFAP and NeuN confirmed transgene expression exclusively in neurons (Fig. 2). Finally, neither the morphology nor the distribution of GFAPpositive radial glial cells in the DG and in the SGZ was substantially altered in $\mathrm{Tg} 1 /$ Tg2 mice (data not shown). Together, the above findings showed that the spatiotemporal pattern of Reelin transgene expression in $\mathrm{Tg} 1 / \mathrm{Tg} 2$ mice (forebrainrestricted postnatal expression) matches that reported for the CaMKII $\alpha$ gene (Mayford et al., 1996). Thus, the $T g 1 / T g 2$ transgenic mouse model, which exhibits normal cortical lamination, allowed us to specifically examine Reelin functions in the adult forebrain.

\section{Reelin overexpression alters migration} and lamination in the RMS

To determine whether Reelin overexpression altered adult neurogenesis in the SVZ (Lois and Alvarez-Buylla, 1994; Alvarez-Buylla and Lim, 2004), BrdU pulses were administered at 2 and 5 months, and mice were analyzed $24 \mathrm{~h}$ later. Counts of BrdU-positive proliferative precursors were done at two rostrocaudal levels along the SVZ/RMS. The numbers of proliferating precursors in the SVZ/RMS remained constant in the different genotypes (Fig. 3a,b).

To examine whether migration along

Figure 4. Neurogenesis and migration in the hippocampal SGZ. a, Sections from P25 aged mice immunostained with BrdU antibodies. Mice were injected with BrdU at P15. Control mice show most BrdU-positive cells near the SGZ layer; $\mathrm{Tg} 1 / \mathrm{Tg} 2$ mice show a wider distribution of BrdU-positive cells in the GL. $\boldsymbol{b}$, Densities of BrdU-positive cells in P15-old mice injected with BrdU pulses and killed after $24 \mathrm{~h}, 10 \mathrm{~d}$, or $20 \mathrm{~d}$. Note increased numbers of BrdU-labeled cells in $\operatorname{Tg} 1 / \operatorname{Tg} 2$ mice. c, Low-power micrographs from control and $\operatorname{Tg} 1 / \operatorname{Tg} 2$ hippocampal sections illustrating higher numbers of DCX-positive cells in the dentate gyrus of $\operatorname{Tg} 1 / \operatorname{Tg} 2$ mice. $\boldsymbol{d}$, Counts of PSA-NCAM- and DCX-positive neurons in the dentate gyrus of 5-month and 12-month-aged mice. $\boldsymbol{e}, \boldsymbol{g}$, Photomicrographs demonstrating the radial distribution of BrdU-positive cells and DCX-immunoreactive cells in control and $\operatorname{Tg} 1 / \operatorname{Tg} 2$ mice; note the wider distribution of immunopositive neurons in Reelin-overexpressing mice. $\boldsymbol{f}, \boldsymbol{h}$, Histograms showing radial distribution of BrdU- and DCX-immunopositive neurons in the GL of control and $\mathrm{Tg} 1 / \mathrm{Tg} 2$ mice. Notice that in $\mathrm{Tg} 1 / \mathrm{Tg} 2$ mice, many neurons are not restricted to the inner GL. DiV, Days in vivo; $\mathrm{H}$, hilus; $\mathrm{ML}$, molecular layer; $\mathrm{P} 15$, postnatal day 15 . Data are presented as mean \pm SEM; ${ }^{*} p<0.05 ;{ }^{* * *} p<0.001$; Student's $t$ test. Scale bars: $\boldsymbol{a}, \boldsymbol{c}, 100 \mu \mathrm{m} ; \boldsymbol{e}, \boldsymbol{g}, 50 \mu \mathrm{m}$.

forebrain lysates revealed that adult $\operatorname{Tg} 1 / \operatorname{Tg} 2$ mice showed about a threefold increase in Reelin expression in the cerebral cortex and hippocampus, and about a sevenfold increase in the striatum, compared to control littermates (Fig. 1b). qRT-PCR analyses also demonstrated that reelin transcripts were increased in adult $\operatorname{Tg} 1 / \operatorname{Tg} 2$ mice $(6.2 \pm 0.3$-fold; $p \leq 0.01)$ ). Dab1 protein levels were slightly decreased in these mice (Fig. 1b). Treatment with doxycycline reduced Reelin protein overexpression after 1 week of treatment (supplemental Fig. 2, available at www. jneurosci.org as supplemental material). Histological examination of adult $\mathrm{Tg} 1 / \mathrm{Tg} 2$ mice did not reveal neuroanatomical the RMS was altered in transgenic mice, BrdU-injected mice were analyzed $20 \mathrm{~d}$ after the BrdU pulses. BrdU-labeled cells in the $\mathrm{OB}$ showed a significant reduction in the total number of cells integrated into the granular cell layer (GCL) in young adult mice. This observation suggests impaired migration and a decrease in the number of granule cells successfully reaching the GCL (Fig. $3 c, d$ ). To analyze the distribution of periglomerular neurons, sections were immunoreacted against $\mathrm{TH}$. The vast majority of TH-positive cells were located in the periglomerular layer in controls. In contrast, in Reelin-overexpressing mice, substantial numbers of ectopically located periglomerular neurons were observed in the GCL, and the number of these neurons increased dramatically with age (Fig. $3 e, f)$. Similar counts on parvalbumin-, calretinin-, and calbindin-positive neurons also revealed an ectopic location for these neuronal subpopulations (supplemental Fig. 4, available at www. jneurosci.org as supplemental material). We conclude that 
overexpression of Reelin leads to the mispositioning of periglomerular and granular neurons.

Reelin overexpression alters neurogenesis in the hippocampal SGZ and the migration of newly generated neurons

Hippocampal neurogenesis in the adult DG has been found to be reduced in reeler mutant mice lacking Reelin (Won et al., 2006). To study the role of Reelin in postnatal hippocampal neurogenesis, Tg1/Tg2 mice and control littermates were pulse-labeled with BrdU postnatally (P15) and killed $24 \mathrm{~h}$ later. A $23 \%$ increase in the number of proliferating progenitors was observed in Reelin transgenics (Fig. 4a,b). A substantial number of postnatally born postmitotic neurons disappear by naturally occurring cell death (Ming and Song, 2005). Reelin has been found to activate both the PI3K and the mitogen-activated protein kinase (MAPK) cascades, which control both cell survival and differentiation (Beffert et al., 2002; Simó et al., 2007). We thus examined the numbers of BrdU-positive cells 10 and $20 \mathrm{~d}$ after the BrdU pulses. The DG of Tg1/Tg2 mice displayed a $19-44 \%$ increase in the number of BrdU-positive cells compared to control littermates (Fig. 4a,b). We also stained BrdU-labeled sections (20 d after BrdU injection) with the pan-neuronal marker NeuN. The densities of double-labeled BrdU/NeuN cells was increased in Tg1/ $\mathrm{Tg} 2$ mice, thus supporting the notion that adult neurogenesis is increased in Reelin-overexpressing mice (Fig. 5). To determine the numbers of adult-generated neurons in the DG, sections from 5- and 12-month-old mice were immunolabeled with PSANCAM and doublecortin (DCX) antibodies, which label differentiating granule cells. $\mathrm{Tg} 1 / \mathrm{Tg} 2$ Reelin-overexpressing mice exhibited increases in the numbers of adult-generated granule cells at 5 months, which became more dramatic in 12-month-old animals (Fig. $4 c, d$ ). Furthermore, adult-generated neurons appeared to be more developed and mature in $\mathrm{Tg} 1 / \mathrm{Tg} 2$ mice, showing increasing complexity in their developing dendrites (Fig. $4 c, g)$. Together, these observations indicate that Reelin overexpression causes increased neurogenesis in the postnatal adult DG, and suggest that Reelin influences granule cell differentiation.

Examination of BrdU-pulse-labeled and PSA-NCAM/DCXimmunoreacted sections revealed that while immunoreactive neurons in control mice were restricted to the deeper zone of the GL, in Reelin-overexpressing mice these newly generated neurons displayed a wider distribution along the entire GL, thus indicating abnormal cell positioning (Fig. $4 a, c, e, g$ ). Counts of adult-generated neurons showed that, at both postnatal adult stages, the numbers of neurons ectopically located in the GL increased markedly in $T g 1 / T g 2$ transgenic mice (Fig. $4 f, h$ ). Thus, our results indicate that Reelin overexpression causes abnormal cell migration and positioning of adult-generated granule cells.

\section{Reelin overexpression increases the number of synaptic} contacts and leads to dendritic spine hypertrophy

To address the impact of Reelin expression on synapse formation in the adult hippocampus, we performed an electron microscope study. Electron micrographs of the hippocampal region showed that $\mathrm{Tg} 1 / \mathrm{Tg} 2 \mathrm{mice}$ had an apparent increase in complexity in both the presynaptic and postsynaptic elements, compared to control mice (Fig. $6 a, b$ ). We then focused on the CA1 and DG regions, where the Reelin transgene is widely expressed, and counted the number of synaptic contacts in layers that receive entorhinohippocampal input [i.e., stratum lacunosum moleculare (SLM) in CA1; medial molecular layer (MML) and outer molecular layer $(\mathrm{OML})$ in $\mathrm{DG}]$ and in layers that receive commissural/associative connections [i.e., stratum oriens $(\mathrm{SO})$ and stratum radiatum
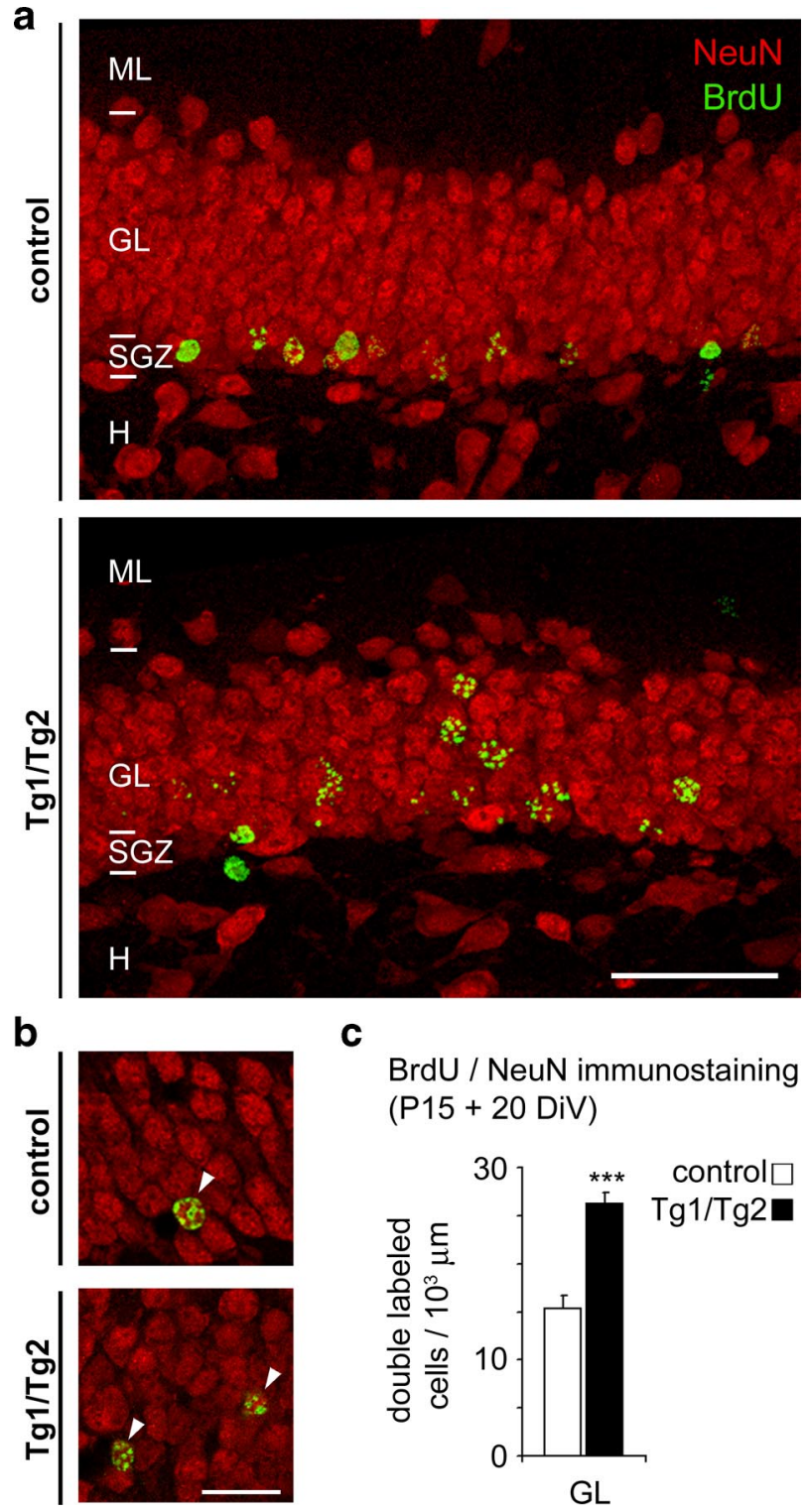

C

BrdU / NeuN immunostaining $(\mathrm{P} 15+20 \mathrm{DiV})$

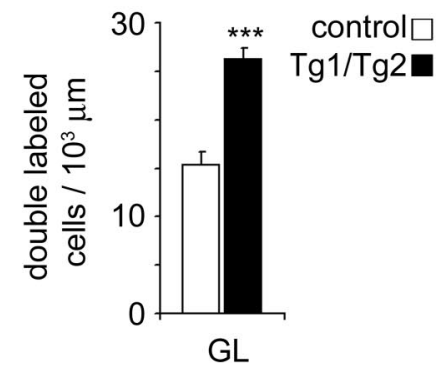

Figure 5. BrdU-labeled cells are NeuN-positive neurons. $\boldsymbol{a}, \boldsymbol{b}$, Confocal photomicrographs showing BrdU/NeuN double-labeled neurons (arrows) in the dentate gyrus of P35-old wt and $\mathrm{Tg} 1 / \mathrm{Tg} 2$ mice injected with BrdU $20 \mathrm{~d}$ before being killed. High-magnification, single-section confocal images are illustrated $(\boldsymbol{b})$. $\boldsymbol{c}$, Histogram showing that densities of BrdU/NeuN neurons increase in the dentate of $\mathrm{Tg} 1 / \mathrm{Tg} 2$ mice. H, Hilus; ML, molecular layer. Data are presented as mean \pm SEM; ${ }^{* * *} p<0.001$; Student's $t$ test. Scale bar: $\boldsymbol{a}, 50 \mu \mathrm{m} ; \boldsymbol{b}, 20 \mu \mathrm{m}$.

(SR) in CA1; inner molecular layer (IML) in DG]. These transgenic mice showed increased density of synaptic contacts in all hippocampal layers. Differences between control and transgenic mice were specially marked in commissural/associative layers containing Schaffer collaterals (SR and SO) in which there was a $32-29 \%$ increase (Fig. $6 a-c$ ). In the remaining hippocampal layers, the increase in synaptic density ranged from $10 \%$ in the IML to $17 \%$ in the OML. Furthermore, the numbers of axon terminals that established two or more synaptic contacts were increased in all hippocampal layers in $T g 1 / T g 2$ mice compared to control littermates (Fig. $6 d$ ). In contrast, electron microscopy quantifications did not reveal any differences in the density of postsynaptic dendritic spines between genotypes (Fig. 6e).

To confirm that these synaptic alterations were caused by Reelin overexpression in the adult brain, $\mathrm{Tg} 1 / \mathrm{Tg} 2$ mice were treated 

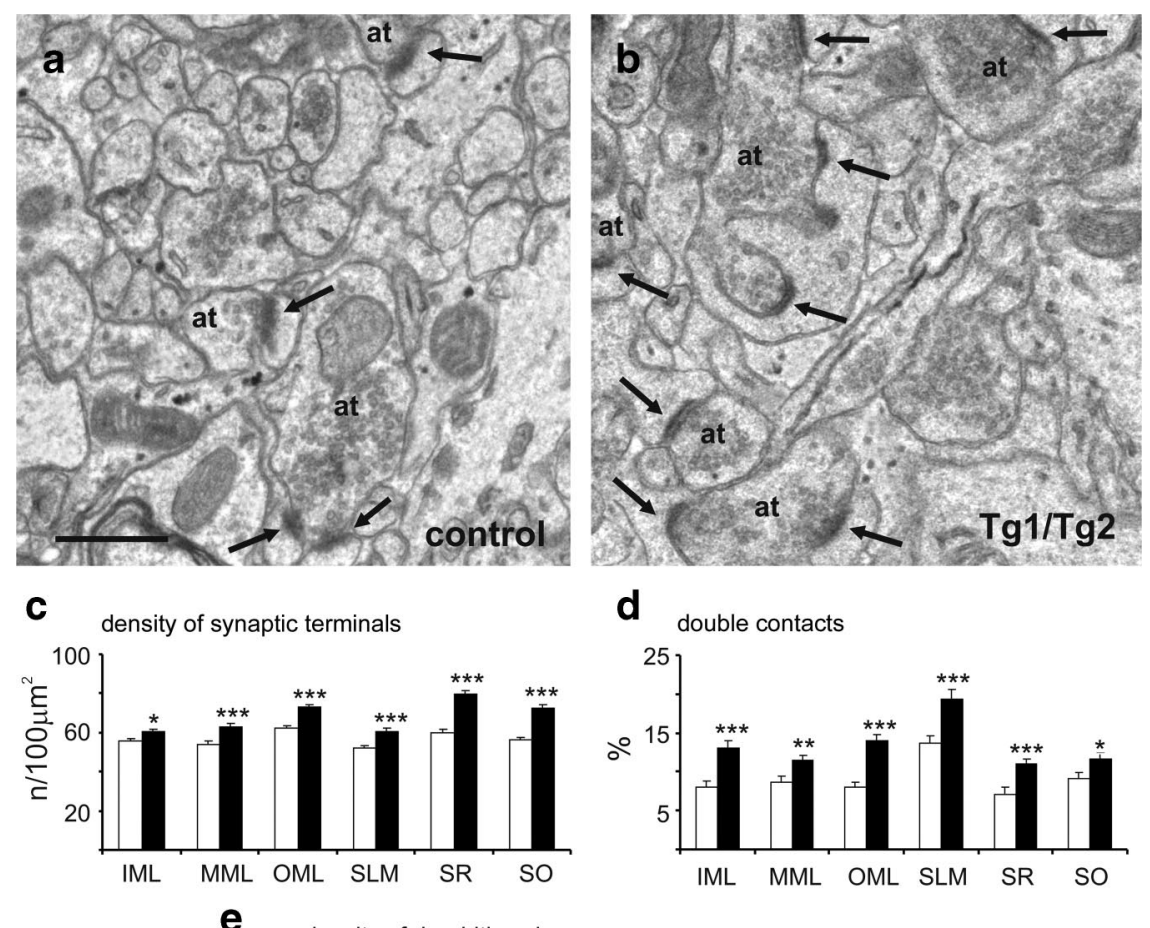

d

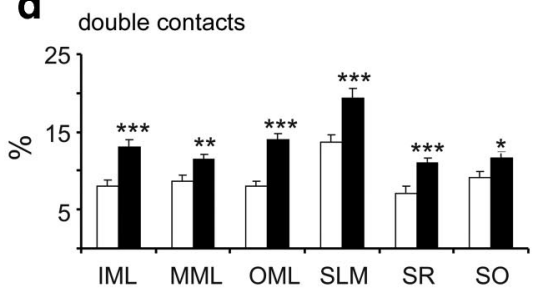

e density of dendritic spines

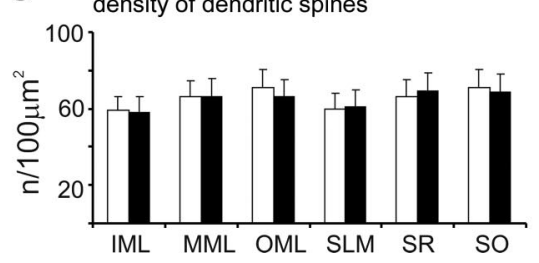

Figure 6. Fine structural features of synaptic contacts in the hippocampus. $\boldsymbol{a}, \boldsymbol{b}$, Electron micrographs illustrating axon terminals and synaptic contacts (arrows) in the IML of control $(\boldsymbol{a})$ and $\operatorname{Tg} 1 / \operatorname{Tg} 2(\boldsymbol{b})$ mice. Note the higher complexity of synaptic boutons and dendritic spines in transgenic mice. $\boldsymbol{c}, \boldsymbol{d}$, Density of synaptic contacts $(\boldsymbol{c})$ and percentage of synaptic terminals establishing at least two contacts $(\boldsymbol{d})$ in different hippocampal layers in $\mathrm{Tg} 1 / \mathrm{Tg} 2$ mice and littermate controls. $\boldsymbol{e}$, Density of dendritic spines receiving at least one synaptic contact in different hippocampal layers. at, Axon terminal. Data are presented as mean \pm SEM; ${ }^{*} p<0.05 ;{ }^{* *} p<0.01 ;{ }^{* * *} p<0.001$; Student's $t$ test. Scale bars: $\boldsymbol{a}, \boldsymbol{b}, 0.5 \mu \mathrm{m}$.

with doxycycline for 1 week before being killed (with Reelin protein levels returning to normal values; see supplemental Fig. 2, available at www.jneurosci.org as supplemental material), and then quantitative fine structural studies were performed as above. We observed that the increase in synaptic contacts seen in $T g 1 / T g 2$ mice was completely reversed when these animals were treated with doxycycline (Fig. $7 a-c$ ). Furthermore, the phenotypes regarding percentages of double-synaptic contacts and densities of dendritic spines were not only reversed upon doxycycline treatment, but tended to reach values that were lower than those in littermate control mice (Fig. $7 d, e$ ). Altogether the above findings indicate that the synaptic phenotype observed in $\mathrm{Tg} 1 / \mathrm{Tg} 2$ mice are largely due to Reelin overexpression in the adult brain. Moreover, the discovery that stopping Reelin overexpression decreases dendritic spine density and the percentage of double-synaptic contacts to values below those in $w t$ animals reinforces the notion that transgenic Reelin is biologically active and that overactivation of the Reelin signaling pathway might lead to desensitization mechanisms.

Finally, analyses of electron micrographs revealed that dendritic spines in $\operatorname{Tg} 1 / \mathrm{Tg} 2$ mice were larger and more complex than in their control littermates. In fact, in Reelin-overexpressing mice, it was frequent to find very large, mushroom-shaped dendritic spines, which were only exceptionally observed in controls
(Figs. 6a, $b, 7 a$ ). These complex spines often had two or more synaptic active zones, and are similar to those reported to be induced after learning and LTP (Yuste and Bonhoeffer, 2001). To corroborate these findings, serial electron micrograph reconstructions were performed in CA1 pyramidal dendrites in the SR (Fig. 8). In control mice, most of the reconstructed dendritic spines were simple, bearing a thin-type appearance (Yuste and Bonhoeffer, 2001; Bourne and Harris, 2008), had small head spines of $\sim 0.3-0.4 \mu \mathrm{m}$ in diameter $(<0.4 \mu \mathrm{m}, 18$ of 31 dendritic spines), and exhibited a single synaptic contact per spine (Fig. $8 a-d$; supplemental Video 1, available at www.jneurosci. org as supplemental material). In contrast, in $T g 1 / T g 2$ mice, most dendritic spines exhibited a mushroom-type phenotype and marked hypertrophy, with large head sizes ( $>0.4 \mu \mathrm{m}$ in diameter, 18 of 28$)$ and two or more synaptic contacts per spine (Fig. $8 e-h$; supplemental Video 2, available at www.jneurosci.org as supplemental material). Some dendritic spines, in fact, displayed extremely large heads of $\sim 1 \mu \mathrm{m}$ in diameter (Fig. $8 e-h$ ). These findings indicate that Reelin overexpression leads to an enlargement and hypertrophy of dendritic spines, which is associated with complex and multiple synaptic junctions.

\section{Hippocampal neurons fail to show paired-pulse depression in Reelin-overexpressing mice}

The above observations suggested that the structural synaptic alterations in Reelinoverexpressing mice are reflected in neurophysiological synaptic properties. To characterize the physiological impact of Reelin overexpression, we focused on the hippocampal CA3-CA1 synapse. Schaffer collaterals originate in the CA3 pyramidal neurons and terminate in the ipsilateral $\mathrm{SO}$ and SR. The physiology of the CA3-CA1 synapse was monitored in alertbehaving animals (11 Tg1/Tg2 mice and 13 control littermates) by stimulating Schaffer collaterals with paired pulses (100 $\mu$ s square, biphasic pulses) and by recording the field EPSPs (fEPSPs) evoked in the ipsilateral CA1 region. Successive paired pulses were presented by gradually increasing the intensity of stimulation. fEPSP responses to the first $\left(\right.$ fEPSP $\left.^{1}\right)$ and second $\left(\right.$ fEPSP $^{2}$ ) pulses were recorded and represented for each intensity. We also took the sum of fEPSP ${ }^{1}$ and fEPSP $^{2}$ responses $\left(\mathrm{fEPSP}^{1+2}\right.$ ) as a global measure of the synapse to a paired-pulse stimulus (Fig. 9a,b).

To characterize the physiology of the CA3-CA1 synapse, we first analyzed paired-pulse facilitation (PPF), measured as the increase in fEPSP $^{2}$ responses compared to fEPSP ${ }^{1}$ (Zucker and Regehr, 2002; Lauri et al., 2007; Citri and Malenka, 2008), at intermediate intensities of stimulation (30\% of the saturation values) and at a wide range of interstimulus intervals (10-1000 $\mathrm{ms})$. We found that PPF peaked at $40 \mathrm{~ms}$ and disappeared at subsequent stimulation intervals in both groups, thereby suggesting that PPF responses under normal physiological conditions 
are similar in control and $T g 1 / \mathrm{Tg} 2$ hippocampi (data not shown). We next studied PPF responses at a range of intensities of stimulation (from 20 to $300 \mu \mathrm{A}$ ), at a fixed $40 \mathrm{~ms}$ interstimulus intervals. Increased intensities of first pulse led to steady increases in fEPSP ${ }^{1}$ responses in both experimental groups (Fig. 9a). Similarly, at low and medium intensity of stimulation, fEPSP $^{2}$ were greater than fEPSP ${ }^{1}$ responses in both control and $\mathrm{Tg} 1 / \mathrm{Tg} 2$ mice (i.e., relation $\mathrm{fEPSP}^{2} /$ fEPSP $^{1}>1$ ), again reinforcing similar PPF patterns (Fig. 9a,b). When the intensity of paired-pulse stimulation was increased in control mice, there was a shift in most animals (9 of 13) so that fEPSP ${ }^{2}$ responses were markedly decreased. In fact, the relation between first and second fEPSPs response was inverted (fEPSP ${ }^{2} /$ fEPSP $\left.^{1}<1\right)$, indicating a paired-pulse depression (PPD) (Fig. 9a,b). In contrast, in $T g 1 / T g 2$ mice, fEPSP ${ }^{2}$ recordings were not reduced even at the highest stimulation intensities used in this study, thereby indicating that the shift from PPF to PPD presents a lower probability in $T g 1 / T g 2$ mice (only 3 of 11 mice exhibited PPD) (Fig. $9 a, b)$. This observation suggested that hippocampal synaptic responses are facilitated in Tg1/Tg2 Reelin-overexpressing mice. Alternatively, $\mathrm{Tg} 1 / \mathrm{Tg} 2$ Reelin-overexpressing mice may lack homeostatic protective mechanisms, such as those already described in wild-type mice, which modulate the response to a second input to the CA3CA1 synapse in function of the intensity of a preceding afferent volley input (for details, see Madroñal et al., 2009).

\section{Reelin overexpression enhances}

\section{LTP responses evoked in alert-behaving mice}

To further investigate synaptic facilitation, we evoked LTP in both groups of animals. To set basal individual conditions, we first recorded in vivo responses in the CA1 region after stimulation of Schaffer collaterals (every $20 \mathrm{~s}$ with a pulse adjusted to $30 \%$ of saturation values). LTP was then evoked on the CA3-CA1 synapse by an HFS protocol [i.e., six repetitions spaced $1 \mathrm{~min}$, each consisting of five trains $(200 \mathrm{~Hz}, 100 \mathrm{~ms})$ at a rate of $1 / \mathrm{s}$ ] (Gruart et al., 2006). Following the HFS session, animals were continuously recorded over $120 \mathrm{~min}$, using the same stimulation protocol applied to generate the baseline. In agreement with previous studies in behaving mice (Gruart et al., 2006), LTP induction in controls resulted in about a 3- to 3.5-fold increase in fEPSP responses (Fig. $9 c-e$ ). In contrast, LTP induction in Reelin-overexpressing mice led to a marked rise in potentiation averaging about a 6- to 6.5-fold increase in fEPSP responses (Fig. $9 c-e)$. The data show that Reelin overexpression significantly increases early LTP responses, which is consistent with the original ex vivo findings in hippocampal slices (Weeber et al., 2002).

To examine the long-lasting effects of Reelin on LTP responses, mice were continuously recorded over several days following the HFS session. Both control and transgenic animals exhibited a decline in fEPSP responses after 2-7 d. However, LTP fEPSP responses in $T g 1 / T g 2$ mice were consistently twofold higher than those recorded in their control littermates (Fig. $9 c-e$ ). Thus, our results indicate that Reelin overexpression significantly enhances LTP responses in the CA3-CA1 synapse both at short times after HFS and during the extinction period. These findings show that $\operatorname{Tg} 1 / \operatorname{Tg} 2$ mice have a strong potentiation of the changes in synaptic strength evoked by HFS.

\section{Reelin overexpression leads to increased neuronal activity during classical conditioning}

We next addressed whether such enhanced potentiation could also be involved in activity-dependent synaptic changes evoked during an associative learning task. We thus examined the effect of Reelin on the CA3-CA1 synapse during a classical eyeblink conditioning, using a hippocampus-dependent trace conditioning paradigm (Gruart et al., 2006). It is known that classical conditioning of eyelid responses induce physiological potentiation in the CA3-CA1 synapse that can be monitored in behaving mice (Gruart et al., 2006; Madroñal et al., 2007). Eyelid conditioned responses were evoked by using a tone $(20 \mathrm{~ms}, 2.4 \mathrm{kHz}, 85 \mathrm{~dB})$ as a CS followed $500 \mathrm{~ms}$ later by an electrical stimulus presented to the supraorbital nerve as a US. fEPSPs evoked at the 

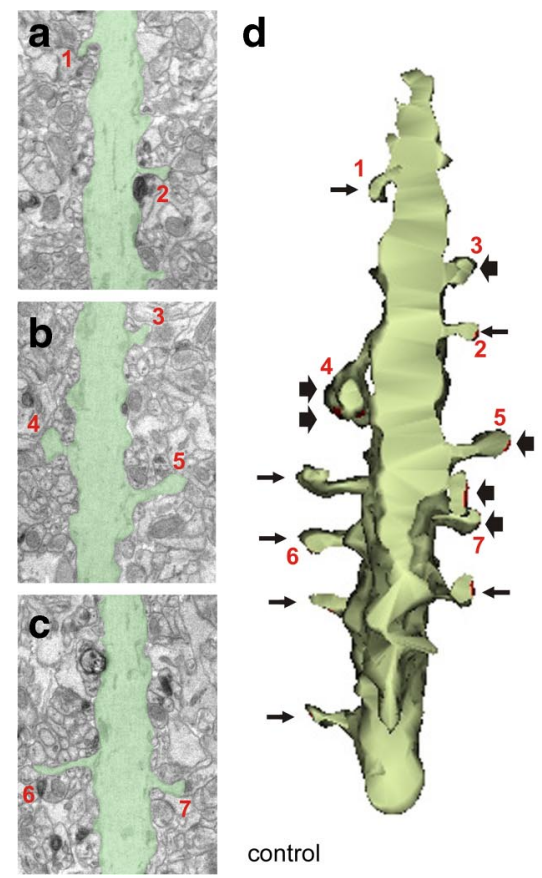

control

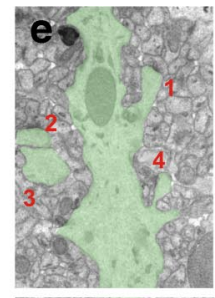

h

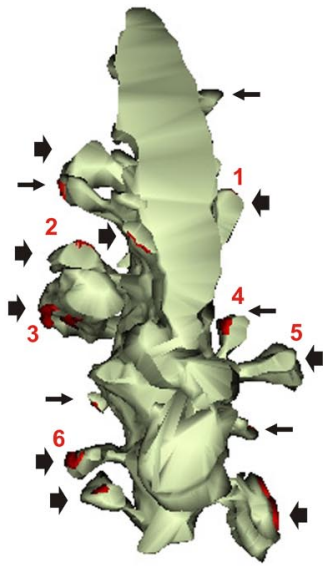

$\operatorname{Tg} 1 / \operatorname{Tg} 2$
Discussion

\section{Reelin control of adult neurogenesis} and migration

To unravel the functions of Reelin in the adult brain, we generated a transgenic mouse line that overexpresses Reelin under the control of the CaMKII $\alpha$ promoter. Because Reelin is essential in brain development, we mainly addressed the impact of Reelin protein levels on developmental-like processes that remain active in the adult brain, namely adult neurogenesis, neural migration, and synaptic plasticity. Our data show that alteration of Reelin expression does not produce changes in the rate of adult neurogenesis in the SVZ, although this region is surrounded by brain areas that exhibit high expression of the transgene (namely, cerebral cortex and striatum). In contrast, the pattern of neuronal migration generated in the SVZ, both granule cells and periglomerular neurons, is altered in Tg1/ Tg2 mice. In fact, the location of ectopic periglomerular neurons in the GCL and the reduced number of granular cells in the GCL suggest that the overexpression of Reelin arrests the migration of these newly generated neurons. Recent data have shown that in vitro incubation with recombinant Reelin causes a detachment of neuroblast migrating chains from the RMS, in a process that is interpreted as a switch from tangential migration to radial glia-controlled mi-

CA3-CA1 synapse were recorded $200 \mathrm{~ms}$ after the CS presentation across the successive habituation, conditioning, and extinction sessions (Fig. 10a) (Gruart et al., 2006). Eyelid conditioned responses increased steadily in both groups of mice (9 Tg1/Tg2 and 11 control mice) across the successive conditioning sessions; however, EMG conditioned responses were larger in Tg1/Tg2 mice than in controls, and significant differences with the habituation period were reached earlier in Reelin-overexpressing mice (Fig. 10b).

Extracellular synaptic field recordings in the CA1 region revealed significant potentiation of the fEPSP response in control mice from the fifth conditioning session onwards (Gruart et al., 2006), reaching $75 \%$ potentiation at day 10 . Reelinoverexpressing mice also showed an increase in the potentiation of the fEPSP response during the conditioning period. However, such increases were already significant by the second conditioning session, and fEPSP responses were consistently higher ( $p \leq$ 0.05) than in their control littermates during the whole conditioning period (Fig. 10c,d). Moreover, during the extinction period, $\mathrm{Tg} 1 / \mathrm{Tg} 2$ mice exhibited a dramatic rise in fEPSP responses compared to controls (Fig. $10 c, d)(p \leq 0.05)$. These results confirm that fEPSPs evoked at the CA3-CA1 synapse are potentiated in parallel with the acquisition of an associative learning task (Gruart et al., 2006; Madroñal et al., 2007), and show that these activity-dependent synaptic changes are increased in Reelinoverexpressing mice. As a whole, we conclude that Reelinoverexpression leads to a marked potentiation of the CA3-CA1 synapse under both physiological (classical conditioning) and nonphysiological (experimentally evoked LTP) conditions. gration, inside the OB (Hack et al., 2002; Simó et al., 2007). The phenotype observed in $\mathrm{Tg} 1 / \mathrm{Tg} 2$ mice is therefore consistent with these studies and suggests that adequate Reelin levels are required to achieve successful neuronal migration in the RMS.

The hippocampal SGZ neurogenic niche, which is essential for learning and memory, is active throughout the entire life (Kee et al., 2007; Zhao et al., 2008). Our data show that the rates of neurogenesis and neuronal incorporation in the DG are increased both during postnatal development and adult stages in Reelin-overexpressing mice. These data are consistent with studies in reeler mice, which have shown a lower rate of neurogenesis (Won et al., 2006). Our results thus support a direct effect of Reelin on adult neurogenesis, which cannot be attributable to the abnormal layering observed in reeler mice. Our data provide evidence that Reelin overexpression increases the numbers of proliferating progenitors in the hippocampal SGZ, thereby suggesting a direct effect of this extracellular protein on hippocampal progenitors. This effect could be achieved by modulating the cycling properties of neural progenitors [as occurs in p21-/mutants (Kippin et al., 2005)], although in $T g 1 / T g 2$ mice we did not observe depletion of neural niches by means of DCX staining even in 12-month-old animals. Recent evidence indicates that a substantial number of neural progenitors disappear by cell death during adult life (Dupret et al., 2007). Finally, and because the Reelin signaling cascade activates both the ERK and PI3K pathways (Beffert et al., 2002; Simó et al., 2007), we cannot exclude the possibility that Reelin may increase the survival of progenitors, and consequently, may lead to slower depletion of hippocampal neural niches. This possibility is also consistent with the finding 
that differences in numbers of newly generated neurons are much more dramatic in old $\mathrm{Tg} 1 / \mathrm{Tg} 2$ transgenic mice than in young adult animals (Fig. $4 c$ ).

Moreover, our data demonstrate that overexpression of Reelin results in a dispersion and abnormal positioning of adult-generated neurons within the GL throughout life. Given that Reelin deficiency also leads to abnormal neuronal migration and lamination (Drakew et al., 2002; Zhao et al., 2004; Gong et al., 2007), our results suggest that Reelin levels, both below and above a certain threshold, impair neuronal migration. However, it is also possible that the ectopic expression of Reelin in the GL of adult $\mathrm{Tg} 1 / \mathrm{Tg} 2$ mice contributes to the altered migration observed in the DG.

\section{Reelin overexpression alters the structural and functional properties of adult synapses}

Previous studies have shown that Reelindeficient reeler and heterozygous mice display a reduced number of dendritic spines in pyramidal neurons. Moreover, incubation of cultured reeler hippocampal neurons with Reelin increases the density of dendritic spines (Niu et al., 2008). Here we show that Reelin overexpression in adult mice does not alter the number of dendritic spines in the hippocampus but does affect their structural properties. This apparent discrepancy could be explained in several ways. First, both reeler and heterozygous mice have increased Dab1 levels, a transducer adaptor required for most Reelin functions, including dendritogenesis (Rice et al., 1998; Howell et al., 1999; Niu et al., 2004; Olson et al., 2006). This is particularly evident in reeler mice, which express a sevenfold increase in Dab1 protein (Rice et al., 1998). It is therefore likely that application of Reelin to reeler neurons leads to hyperactivation of the Reelin signaling pathway. Dab1 protein expression was not upregulated in our $T g 1 / T g 2$ Reelin transgenics. Second, it is also possible that normal Reelin levels are required to achieve standard numbers of dendritic spines, and that above a certain threshold of activation, Reelin overexpression is not sufficient to modify these numbers. Third, it is also feasible that adult neurons, by homeostatic physiological regulation, are specified to develop a maximum number of dendritic spines. Whatever the reason, our results show that Reelin overexpression in a $w t$ background in vivo does not alter spine density in adult hippocampal neurons. Finally, our finding that doxycycline treatment of $\mathrm{Tg} 1 / \mathrm{Tg} 2$ mice strongly reverses the synaptic phenotype in adult mice indicates

$\mathbf{a}_{\text {control }}$

b

control

C

d
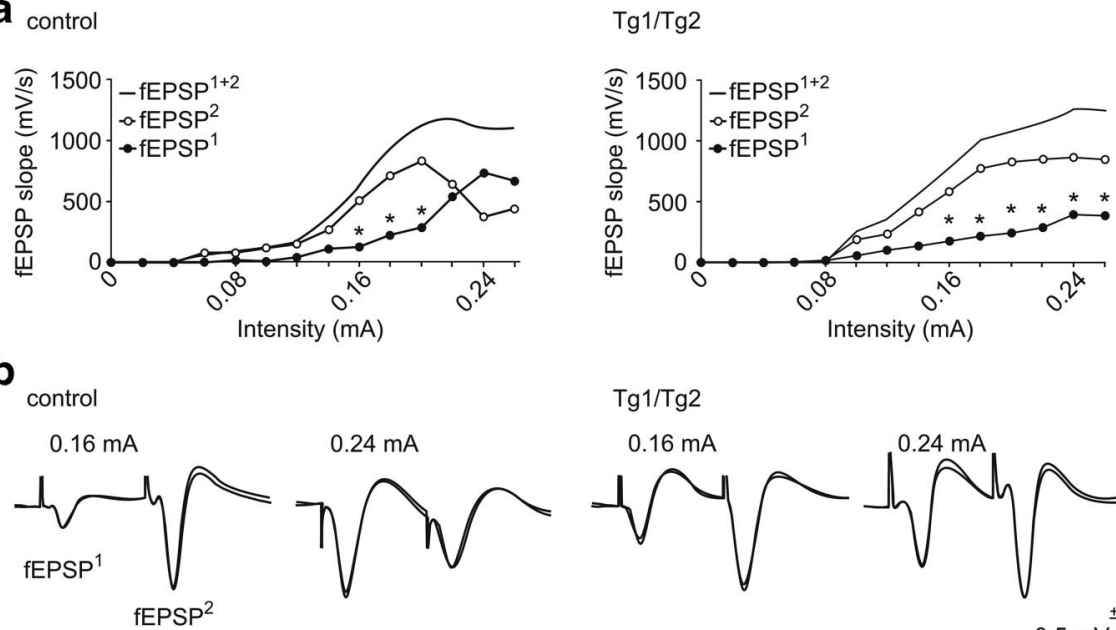

$\operatorname{Tg} 1 / \operatorname{Tg} 2$

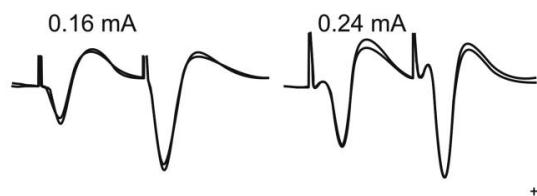

$0.5 \mathrm{mV}]$
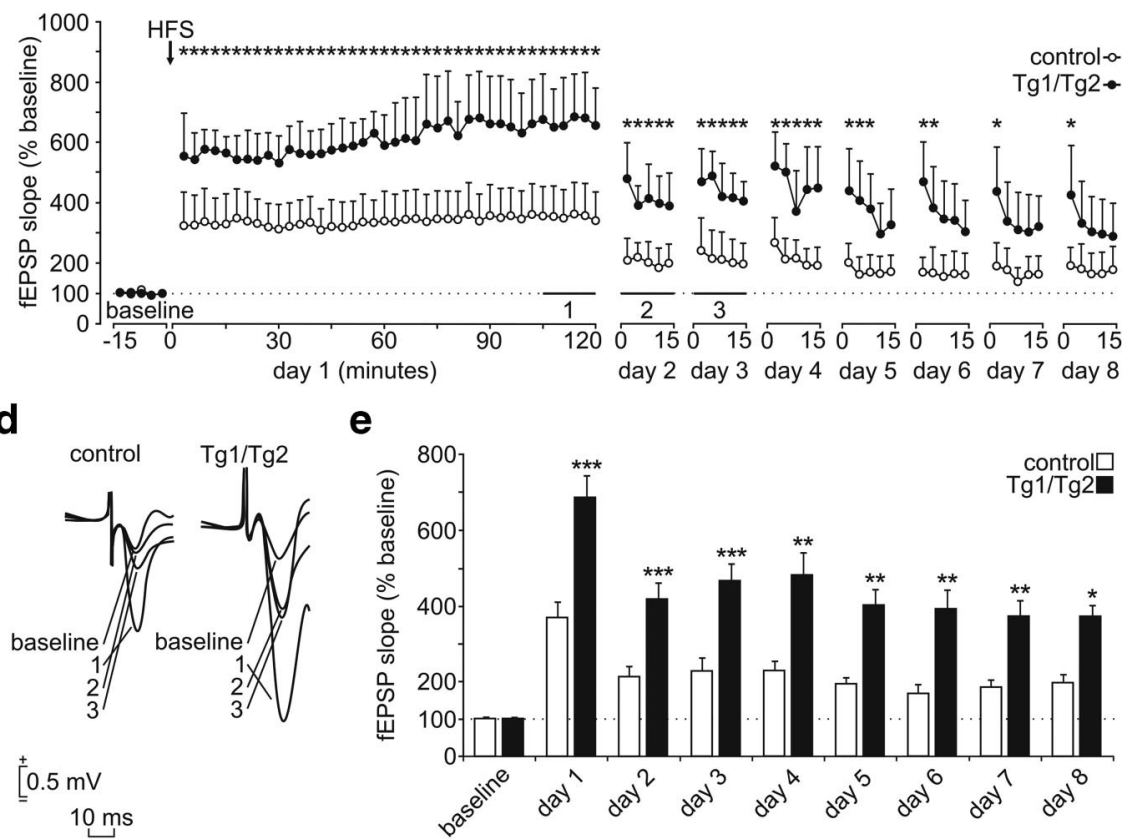

Figure 9. In vivo induction of LTP in the CA1 area after electrical stimulation of the Schaffer collaterals in control and $\mathrm{Tg} 1 / \mathrm{Tg} 2$ mice. $\boldsymbol{a}$, Individual mice were subjected to paired pulses ( $40 \mathrm{~ms}$ interstimulus interval) presented at the CA3-CA1 synapse at increasing intensities of stimulation. PPF is observed in both control $\left({ }^{*} p \leq 0.05\right)$ and $\operatorname{Tg} 1 / \operatorname{Tg} 2\left({ }^{*} p \leq 0.05\right)$ mice at low stimulation intensities $(\leq 0.2 \mathrm{~mA})$. Control mice (left) switch from PPF to paired-pulse depression (PPD) at certain intensity values once they have reached a plateau of global synapse response [fEPSP ${ }^{1+2}$ represents the addition of the first (fEPSP ${ }^{1}$ ) and the second (fEPSP ${ }^{2}$ ) evoked field synaptic responses]. $\operatorname{Tg} 1 / \operatorname{Tg} 2$ mice (right) also reach a plateau at similar intensity values, but inversion from PPF to PPD does not occur $\left({ }^{*} p \leq 0.05\right) \cdot \boldsymbol{b}$, fEPSP profiles evoked by paired pulses collected from representative animals at intermediate $(0.16$ $\mathrm{mA}$; i.e., $\sim 30 \%$ of fEPSP ${ }^{1+2}$ asymptotic values) and high $(0.24 \mathrm{~mA})$ stimulus intensities. Note that controls (left) and $\operatorname{Tg} 1 / \operatorname{Tg} 2$ mice (right) show similar profiles and equal PPF at the intermediate intensity level, but not at the high one. Calibrations are as indicated. c, fEPSP slopes evoked during the whole LTP experiment given as a percentage of the baseline (100\%) values. Immediately after, fEPSPs were recorded for $2 \mathrm{~h}$ (day 1). To further check LTP evolution, fEPSPs were recorded for 15 min during the following days $(2-8)$. Note that $\operatorname{Tg} 1 / \mathrm{Tg} 2$ mice present a significantly $\left(F_{(79,136)}=5.83 ; p \leq 0.05\right)$ larger LTP induction that is still present for the next $7 \mathrm{~d}$. Data are presented as mean \pm SEM. $\boldsymbol{d}$, Representative fEPSP profiles from individual animals collected from control and T1/Tg2 mice during LTP evolution: baseline and $2 \mathrm{~h}(1), 24 \mathrm{~h}$ (2), and $48 \mathrm{~h}$ (3) after HFS. Illustrations are superimposed to show the time course evolution of representative individual profiles. $\boldsymbol{e}$, Mean fEPSP slopes obtained during $15 \mathrm{~min}$ of recording for the two groups of animals $(n=15$ each) were quantified at different times during LTP evolution. Data are presented as mean $\pm \operatorname{SEM}\left(F_{(8,72)}=12,452 ;{ }^{*} p<0.05 ;{ }^{* *} p<0.01 ;{ }^{* * *} p<0.001\right)$.

that said phenotype depends on acute overexpression of Reelin, rather than on the developmental effects of Reelin.

Perhaps the most striking synaptic phenotypic feature of Reelin-overexpressing $\mathrm{Tg} 1 / \mathrm{Tg} 2$ mice is the formation of very 
a

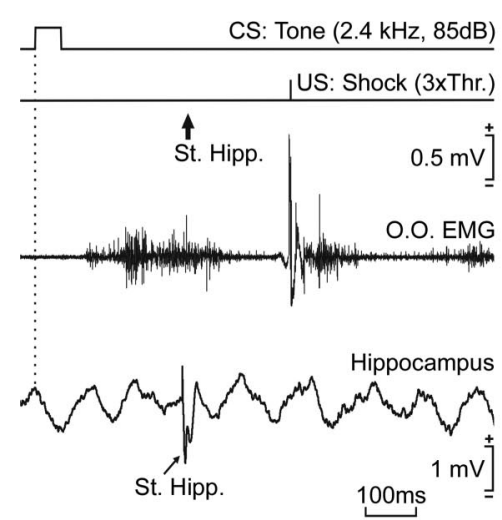

C

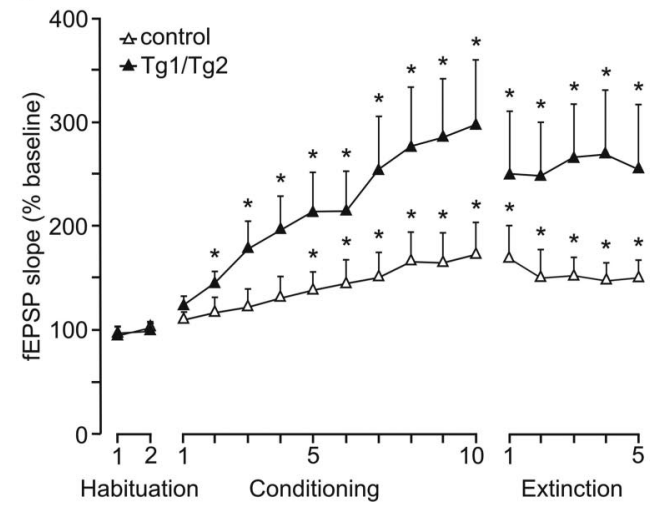

Figure 10. Learning curves and evolution of CA3-CA1 extracellular synaptic field potentials for control and $\operatorname{Tg} 1 / \operatorname{Tg} 2$ mice. $\boldsymbol{a}, A$ schematic representation of the classical conditioning paradigm, illustrating $C S$ and US stimuli and the moment at which a single pulse (100 $\mu$ s; square; biphasic) was presented to Schaffer collaterals (St. Hipp.). An example of an EMG recording from the orbicularis oculi (0.0.) muscle obtained from the 10th conditioning session is illustrated, as well as an extracellular recording of hippocampal activity from the same animal, session, and trial. $\boldsymbol{b}$, Evolution of the increment (\% over baseline values) of eyelid conditioned responses during the whole conditioning protocol. For both groups of animals, the increment in conditioned responses was significantly larger than values collected during habituation sessions at the indicated sessions $\left(F_{(16,144)}=14,810\right.$; ${ }^{*} p<$ 0.001). Moreover, $\operatorname{Tg} 1 / \operatorname{Tg} 2$ mice presented larger increases ( $p \leq 0.05$ ) of conditioned responses than controls from the fifth to the tenth conditioning sessions. $c$, Representative fEPSPs recorded in the CA1 area following a single pulse presented to the ipsilateral Schaffer collaterals $300 \mathrm{~ms}$ after (S presentation. fEPSPs were collected from both control and $\mathrm{Tg} 1 / \mathrm{Tg} 2 \mathrm{groups}$. fEPSP slopes were significantly larger than baseline values at the indicated sessions $\left(F_{(16,144)}=14,375 ;{ }^{*} p<0.001\right)$. fEPSPs evoked in $\operatorname{Tg} 1 / \operatorname{Tg} 2$ mice reached larger slopes than controls from the fifth conditioning session to the fifth extinction one. $\boldsymbol{d}$, Superimposed fEPSP profiles corresponding to habituation session 1 (baseline) and from the 10th conditioning session (conditioned). Mean percentage values are followed by \pm SEM.

large, expanded dendritic spines. Most of these spines display typical mushroom-type shapes and two or more synaptic active zones. This feature was correlated with increased numbers of synapses in all hippocampal layers. Persistent dendritic spine enlargement is commonly associated with increased physiological efficacy and stable LTP, and the latter is thought to underlie long-lasting memory and learning (Yuste and Bonhoeffer, 2001; Yang et al., 2008). One of the questions raised by these structural features is how they are correlated with the functional electrophysiological properties of hippocampal neurons. To address this question, we monitored the physiological properties of the CA3-CA1 synapse in adult mice in vivo under specific experimental conditions, which included intensity tests, electrical-evoked LTP, and classical conditioning. Our electrophysiological data revealed that, in contrast to controls, Reelin-overexpressing hippocampal neurons do not exhibit the shift from PPF to PPD at high stimulation intensities. When evoked in behaving animals, PPD is likely to be the result of the activation of disynaptic inhibitory circuits or to reflect synaptic fatigue caused by massive exocytosis of the re- leasable pool of synaptic vesicles, as a result of high stimulation intensities. In Reelin-overexpressing mice, electrophysiological saturation was also reached although the shift from PPF to PPD did not typically occur (in $72.7 \%$ of cases), even at high stimulation intensities. This finding suggests that adult transgenic neurons respond better to repetitive and highintensity stimulation than $w t$ neurons.

Experimentally evoked LTP in behaving mice is a method that allows analysis of the malleability of hippocampal connectivity in physiological conditions as well as the monitoring of the evolution of LTP responses over long periods of time (i.e., days). Interestingly, the present study in behaving mice revealed that LTP responses are increased twofold in the hippocampus of Reelin-overexpressing hippocampi. Moreover, because HFS induction of LTP is likely to overstimulate neurons in a nonphysiological way, we also monitored patterns of hippocampal activity during a classical eyeblink conditioning using a hippocampal-dependent trace paradigm (Gruart et al., 2006). Again, this study showed that during classical conditioning, Reelin-overexpressing neurons are more prone to be activated and to elicit increased electrophysiological responses than those of controls. Interestingly, in both experimental situations (LTP and classical conditioning), persistent robust responses were recorded in $\operatorname{Tg} 1 / \operatorname{Tg} 2$ mice over several days (including the extinction period), as compared to control littermates. Thus, our results indicate that the modeling of Reelin expression enhances physiological plasticity in the CA3-CA1 synapse both during early and late LTP and across the conditioning sessions. This observation implies that in both paradigms activation of the Reelin system is sufficient to drive the structural and molecular changes responsible for short-term and long-term changes in strength and synaptic plasticity.

The present data are consistent with those reported in previous studies showing that ApoER2/VLDLR-deficient mice display reduced LTP in slices in vitro, which suggests that the effects described herein are mediated by these receptors (Weeber et al., 2002; Beffert et al., 2005). Interestingly Reelin has been found to control NMDA and AMPA subunit receptor composition and trafficking during development (Chen et al., 2005; Qiu et al., 2006; Groc et al., 2007), and both types of ionotropic glutamate receptors are essential for LTP induction (Jones et al., 2001; Ju et al., 2004). Furthermore, GSK3 $\beta$, a downstream effector of the Reelin signaling cascade, has been found recently to be involved in LTP (Peineau et al., 2007). Together, our data suggest that extracellular Reelin, which localizes at synapses (Pesold et al., 1998; Groc et al., 2007), acts via the ApoER2/VLDLR receptors to trigger a signaling cascade that is sufficient to induce marked LTP physiological alterations in vivo. Moreover, we show that Reelin overexpression also leads to increased LTP 
responses over several days, which suggests that this extracellular protein controls gene expression and protein synthesis required for late phases of LTP (Jones et al., 2001; Ju et al., 2004).

Altogether, our results indicate that in the adult brain Reelin levels are crucial for the modulation of neurogenesis and migration, particularly in the hippocampus, as well as for the modulation of the structural and functional plastic properties of adult synapses, including induction and maintenance of LTP. Thus, Reelin, a protein with pivotal roles in normal development, also controls plasticity processes in the adult brain that are reminiscent of developmental processes. Finally, the modulation of adult neurogenesis by Reelin (which is closely related to learning), as well as the recent findings implicating Reelin alterations in Alzheimer's disease and the observation that $\beta$-amyloid species inhibit synaptic strength and LTP, points to molecular cross talk between Reelin and APP (Botella-López et al., 2006; Durakoglugil et al., 2009; Hoe et al., 2009; Knuesel et al., 2009). This cross talk may be relevant in the synaptopathology and learning deficits associated with Alzheimer's disease.

\section{References}

Alcántara S, Ruiz M, D’Arcangelo G, Ezan F, de Lecea L, Curran T, Sotelo C, Soriano E (1998) Regional and cellular patterns of reelin mRNA expression in the forebrain of the developing and adult mouse. J Neurosci 18:7779-7799.

Alvarez-Buylla A, Lim DA (2004) For the long run: maintaining germinal niches in the adult brain. Neuron 41:683-686.

Arnaud L, Ballif BA, Förster E, Cooper JA (2003) Fyn tyrosine kinase is a critical regulator of disabled-1 during brain development. Curr Biol 13:9-17.

Ballif BA, Arnaud L, Arthur WT, Guris D, Imamoto A, Cooper JA (2004) Activation of a Dab1/CrkL/C3G/Rap1 pathway in Reelin-stimulated neurons. Curr Biol 14:606-610.

Beffert U, Morfini G, Bock HH, Reyna H, Brady ST, Herz J (2002) Reelinmediated signaling locally regulates protein kinase B/Akt and glycogen synthase kinase 3beta. J Biol Chem 277:49958-49964.

Beffert U, Weeber EJ, Durudas A, Qiu S, Masiulis I, Sweatt JD, Li WP, Adelmann G, Frotscher M, Hammer RE, Herz J (2005) Modulation of synaptic plasticity and memory by Reelin involves differential splicing of the lipoprotein receptor Apoer2. Neuron 47:567-579.

Beffert U, Durudas A, Weeber EJ, Stolt PC, Giehl KM, Sweatt JD, Hammer RE, Herz J (2006) Functional dissection of Reelin signaling by sitedirected disruption of Disabled-1 adaptor binding to apolipoprotein $\mathrm{E}$ receptor 2: distinct roles in development and synaptic plasticity. J Neurosci 26:2041-2052.

Bliss TV, Gardner-Medwin AR (1973) Long-lasting potentiation of synaptic transmission in the dentate area of the unanaestetized rabbit following stimulation of the perforant path. J Physiol 232:357-374.

Botella-López A, Burgaya F, Gavín R, García-Ayllón MS, Gómez-Tortosa E, Peña-Casanova J, Ureña JM, Del Río JA, Blesa R, Soriano E, Sáez-Valero J (2006) Reelin expression and glycosylation patterns are altered in Alzheimer's disease. Proc Natl Acad Sci U S A 103:5573-5578.

Bourne JN, Harris KM (2008) Balancing structure and function at hippocampal dendritic spines. Annu Rev Neurosci 31:47-67.

Chen Y, Beffert U, Ertunc M, Tang TS, Kavalali ET, Bezprozvanny I, Herz J (2005) Reelin modulates NMDA receptor activity in cortical neurons. J Neurosci 25:8209-8216.

Citri A, Malenka RC (2008) Synaptic plasticity: multiple forms, functions, and mechanisms. Neuropsychopharmacology 33:18-41.

Cooper JA (2008) A mechanism for inside-out lamination in the neocortex. Trends Neurosci 31:113-119.

D’Arcangelo G, Miao GG, Chen SC, Soares HD, Morgan JI, Curran T (1995) A protein related to extracellular matrix proteins deleted in the mouse mutant reeler. Nature 374:719-723.

D’Arcangelo G, Nakajima K, Miyata T, Ogawa M, Mikoshiba K, Curran T (1997) Reelin is a secreted glycoprotein recognized by the CR-50 monoclonal antibody. J Neurosci 17:23-31.

Drakew A, Deller T, Heimrich B, Gebhardt C, Del Turco D, Tielsch A, Förster E, Herz J, Frotscher M (2002) Dentate granule cells in reeler mutants and VLDLR and ApoER2 knockout mice. Exp Neurol 176:12-24.
Dupret D, Fabre A, Döbrössy MD, Panatier A, Rodríguez JJ, Lamarque S, Lemaire V, Oliet SH, Piazza PV, Abrous DN (2007) Spatial learning depends on both the addition and removal of new hippocampal neurons. PLoS Biol 5:e214.

Durakoglugil MS, Chen Y, White CL, Kavalali ET, Herz J (2009) Reelin signaling antagonizes beta-amyloid at the synapse. Proc Natl Acad Sci U S A 106:15938-15943.

Gong C, Wang TW, Huang HS, Parent JM (2007) Reelin regulates neuronal progenitor migration in intact and epileptic hippocampus. J Neurosci 27:1803-1811.

González-Billault C, Del Río JA, Ureña JM, Jiménez-Mateos EM, Barallobre MJ, Pascual M, Pujadas L, Simó S, Torre AL, Gavin R, Wandosell F, Soriano E, Avila J (2005) A role of MAP1B in Reelin-dependent neuronal migration. Cereb Cortex 15:1134-1145.

Groc L, Choquet D, Stephenson FA, Verrier D, Manzoni OJ, Chavis P (2007) NMDA receptor surface trafficking and synaptic subunit composition are developmentally regulated by the extracellular matrix protein Reelin. J Neurosci 27:10165-10175.

Gruart A, Muñoz MD, Delgado-García JM (2006) Involvement of the CA3CA1 synapse in the acquisition of associative learning in behaving mice. J Neurosci 26:1077-1087.

Gureviciene I, Ikonen S, Gurevicius K, Sarkaki A, van Groen T, Pussinen R, Ylinen A, Tanila H (2004) Normal induction but accelerated decay of LTP in APP + PS1 transgenic mice. Neurobiol Dis 15:188-195.

Hack I, Bancila M, Loulier K, Carroll P, Cremer H (2002) Reelin is a detachment signal in tangential chain-migration during postnatal neurogenesis. Nat Neurosci 5:939-945.

Hiesberger T, Trommsdorff M, Howell BW, Goffinet A, Mumby MC, Cooper JA, Herz J (1999) Direct binding of Reelin to VLDL receptor and ApoE receptor 2 induces tyrosine phosphorylation of disabled-1 and modulates tau phosphorylation. Neuron 24:481-489.

Hoe HS, Lee KJ, Carney RS, Lee J, Markova A, Lee JY, Howell BW, Hyman BT, Pak DT, Bu G, Rebeck GW (2009) Interaction of reelin with amyloid precursor protein promotes neurite outgrowth. J Neurosci 29:74597473.

Howell BW, Hawkes R, Soriano P, Cooper JA (1997) Neuronal position in the developing brain is regulated by mouse disabled-1. Nature 389:733-737.

Howell BW, Herrick TM, Cooper JA (1999) Reelin-induced tyrosine [corrected] phosphorylation of disabled 1 during neuronal positioning. Genes Dev 13:643-648.

Impagnatiello F, Guidotti AR, Pesold C, Dwivedi Y, Caruncho H, Pisu MG, Uzunov DP, Smalheiser NR, Davis JM, Pandey GN, Pappas GD, Tueting P, Sharma RP, Costa E (1998) A decrease of reelin expression as a putative vulnerability factor in schizophrenia. Proc Natl Acad Sci U S A 95:15718-15723.

Jones MW, Errington ML, French PJ, Fine A, Bliss TV, Garel S, Charnay P, Bozon B, Laroche S, Davis S (2001) A requirement for the immediate early gene Zif268 in the expression of late LTP and long-term memories. Nat Neurosci 4:289-296.

Ju W, Morishita W, Tsui J, Gaietta G, Deerinck TJ, Adams SR, Garner CC, Tsien RY, Ellisman MH, Malenka RC (2004) Activity-dependent regulation of dendritic synthesis and trafficking of AMPA receptors. Nat Neurosci 7:244-253.

Kee N, Teixeira CM, Wang AH, Frankland PW (2007) Preferential incorporation of adult-generated granule cells into spatial memory networks in the dentate gyrus. Nat Neurosci 10:355-362.

Kippin TE, Martens DJ, van der Kooy D (2005) p21 loss compromises the relative quiescence of forebrain stem cell proliferation leading to exhaustion of their proliferation capacity. Genes Dev 19:756-767.

Knuesel I, Nyffeler M, Mormède C, Muhia M, Meyer U, Pietropaolo S, Yee BK, Pryce CR, LaFerla FM, Marighetto A, Feldon J (2009) Age-related accumulation of Reelin in amyloid-like deposits. Neurobiol Aging 30:697-716.

Lauri SE, Palmer M, Segerstrale M, Vesikansa A, Taira T, Collingridge GL (2007) Presynaptic mechanisms involved in the expression of STP and LTP at CA1 synapses in the hippocampus. Neuropharmacology 52:1-11.

Lois C, Alvarez-Buylla A (1994) Long-distance neuronal migration in the adult mammalian brain. Science 264:1145-1148.

Madroñal N, Delgado-García JM, Gruart A (2007) Differential effects of long-term potentiation evoked at the CA3 CA1 synapse before, during, 
and after the acquisition of classical eyeblink conditioning in behaving mice. J Neurosci 27:12139-12146.

Madroñal N, Gruart A, Delgado-García JM (2009) Differing presynaptic contributions to LTP and associative learning in behaving mice. Frontiers in behavioral neuroscience 3:7.

Magdaleno S, Keshvara L, Curran T (2002) Rescue of ataxia and preplate splitting by ectopic expression of Reelin in reeler mice. Neuron 33: 573-586.

Matsuki T, Pramatarova A, Howell BW (2008) Reduction of Crk and CrkL expression blocks reelin-induced dendritogenesis. J Cell Sci 121:18691875.

Mayford M, Bach ME, Huang YY, Wang L, Hawkins RD, Kandel ER (1996) Control of memory formation through regulated expression of a CaMKII transgene. Science 274:1678-1683.

Ming GL, Song H (2005) Adult neurogenesis in the mammalian central nervous system. Annu Rev Neurosci 28:223-250.

Niu S, Renfro A, Quattrocchi CC, Sheldon M, D'Arcangelo G (2004) Reelin promotes hippocampal dendrite development through the VLDLR/ ApoER2-Dab1 pathway. Neuron 41:71-84.

Niu S, Yabut O, D’Arcangelo G (2008) The Reelin signaling pathway promotes dendritic spine development in hippocampal neurons. J Neurosci 28:10339-10348.

Olson EC, Kim S, Walsh CA (2006) Impaired neuronal positioning and dendritogenesis in the neocortex after cell-autonomous Dab1 suppression. J Neurosci 26:1767-1775.

Paxinos G, Franklin KBJ (2001) The mouse brain in stereotaxic coordinates. London: Academic.

Peineau S, Taghibiglou C, Bradley C, Wong TP, Liu L, Lu J, Lo E, Wu D, Saule E, Bouschet T, Matthews P, Isaac JT, Bortolotto ZA, Wang YT, Collingridge GL (2007) LTP inhibits LTD in the hippocampus via regulation of GSK3beta. Neuron 53:703-717.

Persico AM, D’Agruma L, Maiorano N, Totaro A, Militerni R, Bravaccio C, Wassink TH, Schneider C, Melmed R, Trillo S, Montecchi F, Palermo M, Pascucci T, Puglisi-Allegra S, Reichelt KL, Conciatori M, Marino R, Quattrocchi CC, Baldi A, Zelante L, et al. (2001) Reelin gene alleles and haplotypes as a factor predisposing to autistic disorder. Mol Psychiatry 6:150-159.

Pesold C, Impagnatiello F, Pisu MG, Uzunov DP, Costa E, Guidotti A, Caruncho HJ (1998) Reelin is preferentially expressed in neurons synthe- sizing gamma-aminobutyric acid in cortex and hippocampus of adult rats. Proc Natl Acad Sci U S A 95:3221-3226.

Porras-García E, Cendelin J, Domínguez-del-Toro E, Vozeh F, DelgadoGarcía JM (2005) Purkinje cell loss affects differentially the execution, acquisition and prepulse inhibition of skeletal and facial motor responses in Lurcher mice. Eur J Neurosci 21:979-988.

Qiu S, Zhao LF, Korwek KM, Weeber EJ (2006) Differential reelin-induced enhancement of NMDA and AMPA receptor activity in the adult hippocampus. J Neurosci 26:12943-12955.

Rice DS, Curran T (2001) Role of the reelin signaling pathway in central nervous system development. Annu Rev Neurosci 24:1005-1039.

Rice DS, Sheldon M, D'Arcangelo G, Nakajima K, Goldowitz D, Curran T (1998) Disabled-1 acts downstream of Reelin in a signaling pathway that controls laminar organization in the mammalian brain. Development 125:3719-3729.

Simó S, Pujadas L, Segura MF, La Torre A, Del Río JA, Ureña JM, Comella JX, Soriano E (2007) Reelin induces the detachment of postnatal subventricular zone cells and the expression of the Egr-1 through Erk1/2 activation. Cereb Cortex 17:294-303.

Soriano E, Del Río JA (2005) The cells of Cajal-Retzius: still a mystery one century after. Neuron 46:389-394.

Weeber EJ, Beffert U, Jones C, Christian JM, Forster E, Sweatt JD, Herz J (2002) Reelin and ApoE receptors cooperate to enhance hippocampal synaptic plasticity and learning. J Biol Chem 277:39944-39952.

Won SJ, Kim SH, Xie L, Wang Y, Mao XO, Jin K, Greenberg DA (2006) Reelin-deficient mice show impaired neurogenesis and increased stroke size. Exp Neurol 198:250-259.

Yang Y, Wang XB, Frerking M, Zhou Q (2008) Spine expansion and stabilization associated with long-term potentiation. J Neurosci 28:57405751.

Yuste R, Bonhoeffer T (2001) Morphological changes in dendritic spines associated with long-term synaptic plasticity. Annu Rev Neurosci 24:1071-1089.

Zhao C, Deng W, Gage FH (2008) Mechanisms and functional implications of adult neurogenesis. Cell 132:645-660.

Zhao S, Chai X, Förster E, Frotscher M (2004) Reelin is a positional signal for the lamination of dentate granule cells. Development 131:5117-5125.

Zucker RS, Regehr WG (2002) Short-term synaptic plasticity. Annu Rev Physiol 64:355-405. 